\title{
Delay of natural bone loss by higher intakes of specific minerals and vitamins.
}

Citation for published version (APA):

Schaafsma, A., de Vries, P., \& Saris, W. H. M. (2001). Delay of natural bone loss by higher intakes of specific minerals and vitamins. Critical Reviews in Food Science and Nutrition, 41(3), 225-249. https://doi.org/10.1080/20014091091805

Document status and date:

Published: 01/01/2001

DOI:

10.1080/20014091091805

Document Version:

Publisher's PDF, also known as Version of record

\section{Please check the document version of this publication:}

- A submitted manuscript is the version of the article upon submission and before peer-review. There can be important differences between the submitted version and the official published version of record.

People interested in the research are advised to contact the author for the final version of the publication, or visit the DOI to the publisher's website.

- The final author version and the galley proof are versions of the publication after peer review.

- The final published version features the final layout of the paper including the volume, issue and page numbers.

Link to publication

\footnotetext{
General rights rights.

- You may freely distribute the URL identifying the publication in the public portal. please follow below link for the End User Agreement:

www.umlib.nl/taverne-license

Take down policy

If you believe that this document breaches copyright please contact us at:

repository@maastrichtuniversity.nl

providing details and we will investigate your claim.
}

Copyright and moral rights for the publications made accessible in the public portal are retained by the authors and/or other copyright owners and it is a condition of accessing publications that users recognise and abide by the legal requirements associated with these

- Users may download and print one copy of any publication from the public portal for the purpose of private study or research.

- You may not further distribute the material or use it for any profit-making activity or commercial gain

If the publication is distributed under the terms of Article $25 \mathrm{fa}$ of the Dutch Copyright Act, indicated by the "Taverne" license above, 


\title{
Delay of Natural Bone Loss by Higher Intakes of Specific Minerals and Vitamins
}

\author{
A. Schaafsma, ${ }^{1 *}$ P. J. F. de Vries, ${ }^{1}$ and W. H. M. Saris ${ }^{2}$ \\ 1 Friesland Coberco Dairy Foods, Dep. of Research \& Development Leeuwarden, Leeuwarden, The Netherlands; \\ 2 University Maastricht, Dept. Human Biology, Maastricht, The Netherlands
}

- Corresponding author: A. Schaafsma, Friesland Coberco Dairy Foods, Dept. Research and Development, Leeuwarden, P.O. Box 226, 8901 MA. Leeuwarden, The Netherlands, fax: +31 58 2992540, e-mail: a.schaafsma@fdf.nl.

KEY WORDS: nutrition, bone mineral density, bone metabolism, postmenopausal women

\begin{abstract}
For early prevention or inhibition of postmenopausal and age-related bone loss, nutritional interventions might be a first choice. For some vitamins and minerals an important role in bone metabolism is known or suggested. Calcium and vitamin D support bone mineral density and are basic components in most preventive strategies. Magnesium is involved in a number of activities supporting bone strength, preservation, and remodeling. Fluorine and strontium have bone-forming effects. However, high amounts of both elements may reduce bone strength. Boron is especially effective in case of vitamin D, magnesium, and potassium deficiency. Vitamin $\mathrm{K}$ is essential for the activation of osteocalcin. Vitamin $\mathrm{C}$ is an important stimulus for osteoblast-derived proteins. Increasing the recommended amounts (US RDA 1989), adequate intakes (US DRI 1997), or assumed normal intakes of mentioned food components may lead to a considerable reduction or even prevention of bone loss, especially in late postmenopausal women and the elderly.
\end{abstract}

\section{INTRODUCTION}

Bone loss at an older age ( $>50$ years) will sooner or later lead to osteoporosis and fractures in millions of people associated with a decrease in general well-being and with high costs for health care, especially in the case of hip fractures. ${ }^{.}$Bone mass, architecture, and composition are largely under genetic control and strongly influenced by mechanical stress in an early stage of life. However, to achieve one's genetic potential, adequate nutrition during growth and maintenance is necessary for optimum skeletal development and health. ${ }^{2}$ A first step in the prevention of osteoporosis is a high bone mass during puberty and adolescence. Between peak bone mass and the age of about 50, bone mass has to be preserved by a healthy life style and adequate nutrition. After that period, strategies to preserve bone strength should start as soon as possible. ${ }^{3}$ Although architecture plays an important role in bone strength, a valid and noninvasive predictor of fracture risk at an older age is bone mineral density (BMD). ${ }^{4}$ At an older age, bone mass decreases as a result of aging (type 2 or senile osteoporosis), decreased synthesis of gonadal hormones (type 1 or postmenopausal osteoporosis), and often by malnutrition. Only during the early postmenopausal phase (less than 5 years following menopause), nutritional intervention seems to be less effective. ${ }^{1}$ Vitamin $D$, and especially calcium, return regularly in preventive strategies. However, other food ingredients also play important roles, assisting calcium and vitamin $\mathrm{D}$ or just by completing nutrition. Copper, manganese, and zinc are cofactors for enzymes involved in bone metabolism. ${ }^{5}$ Premenopausal higher intakes of zinc, magnesium, potassium, fiber, and vitamin $\mathrm{C}$ were associated with a higher BMD of the lumbar spine. Positive influences on BMD of the lumbar spine and femoral neck were seen in early adulthood because of adequate milk and fruit intakes. ${ }^{6}$ Fluorine is known to stimulate bone formation. ${ }^{1}$ Such a function has also been suggested for strontium. ${ }^{7}$ The role boron plays in maintaining bone 
mineral density is less clear. ${ }^{8}$ Silicon and aluminum are thought to increase the thickness of trabeculae, whereas aluminum also might increase connectivity of trabecular bone. ${ }^{9}$ However, aluminum is also mentioned as an inhibitor of hydroxyapatite growth. ${ }^{10}$ Vitamin $\mathrm{K}$ is known as a co-factor in the activation of a number of proteins involved in bone metabolism. ${ }^{1}$ This article reviews the current knowledge about the role of calcium, vitamin $\mathrm{D}$, magnesium, strontium, fluorine, boron, vitamin $\mathrm{K}$, and vitamin $\mathrm{C}$ on bone metabolism in postmenopausal women.

\section{CALCIUM}

To secure vital activities, serum calcium concentration is maintained within narrow limits (range 2.1 to $2.6 \mathrm{mmol} / \mathrm{L}$ ), a process controlled by the hormones calcitriol $\left(1,25(\mathrm{OH})_{2} \mathrm{D}_{3}\right)$, parathyroid hormone (PTH), and to a lesser extent calcitonin. ${ }^{11}$ It has been suggested that the calcium intake of postmenopausal women should be at least $1500 \mathrm{mg}$ per day, ${ }^{12}$ which is higher than the U.S. adequate daily intake of $1200 \mathrm{mg} .{ }^{13}$ Important dietary calcium sources are dairy products. ${ }^{14}$ Dark leafy green vegetables are also rich in calcium but often with a lower bioavailability except for Brassica vegetables such as broccoli. ${ }^{15}$ Less well-known calcium sources are fatty fish (the small fish bones included), nuts, and subtropical fruits. ${ }^{16}$ To achieve high calcium intakes, calcium supplements may be necessary that differ in purity, percentage of elemental calcium, and solubility. In subjects without health problems, calcium intakes up to $2,500 \mathrm{mg}$ are safe. ${ }^{13}$ High intakes of calcium are not related to kidney stone formation and might even prevent this by binding dietary oxalate in the intestine. ${ }^{17,18}$ However, increased calcium intakes, already in amounts of $300 \mathrm{mg}$, limit the absorption of dietary iron (including heme iron). ${ }^{18}$ Although this will not harm bone metabolism directly, anemia and tiredness ${ }^{19}$ will negatively affect physical activity, and as a consequence may stimulate bone resorption. Inhibition of zinc absorption can be overcome by zinc supplementation, ${ }^{20}$ whereas a reduced magnesium absorption might be compensated by reduced urinary losses. ${ }^{21}$

\section{A. Absorption and Losses of Calcium}

Reported mean absorption percentages of calcium range from 24 to $35 \% .^{11,13,22}$ Passive calcium absorption, which is determined by amount of calcium consumed, is of major importance for the elderly ( 65 years and older). Their active transport of calcium may be less efficient due to reduced serum calcitriol concentrations and a reduced gastrointestinal sensitivity to calcitriol. ${ }^{1}$ Small differences in intestinal calcium absorbability seem to have a low impact on calcium balance in healthy middle-aged women. Differences in urinary calcium excretion are of major importance. ${ }^{1,23}$ Urinary calcium losses increase after the menopause apparently for a period of 15 to 20 years. ${ }^{11}$ It has been hypothesized ${ }^{24}$ that the rise in bone resorption is secondary to a decreased reabsorption of renal calcium as a result of a lowered sensitivity of the kidneys for PTH because of estrogen deficiency.

\section{B. Effects of Calcium Supplementation in Elderly and Postmenopausal Women}

Increases in trabecular BMD after calcium supplementation, which result from closure of remodeling spaces (the so-called remodeling transient), can be considered as a short-term effect ( 6 to 12 months), ${ }^{25,26}$ but this effect may remain when supplementation is continued. ${ }^{27,28}$ Calcium supplementation reduces bone turnover, possibly by suppressing PTH secretion, ${ }^{1}$ which takes place especially during the first hours after intake. ${ }^{29}$ Vitamin D is also known to inhibit bone resorption by reducing the circulating amounts of PTH. ${ }^{30}$ Senile hyperparathyroidism was treated with a daily dosage of about $1000 \mathrm{mg}$ of calcium in combination with 400 to $800 \mathrm{IU}$ of vitamin D. ${ }^{31-33}$ Menopause-related bone loss already starts during the years immediately preceding menopause. This loss of bone (about $2 \%$ per year) was reduced substantially by supplementation with 1000 or $2000 \mathrm{mg}$ calcium. ${ }^{34}$ During the first 5 to 10 years after menopause bone comes into a new steady state at about a $15 \%$ lower bone mass. ${ }^{35}$ This estrogen deficiency-related bone loss cannot be prevented by calcium supplementation ( 500 to 
$1200 \mathrm{mg}$ ) with ${ }^{36}$ or without vitamin D. Only a moderate inhibition was reported in particular for compact bone ${ }^{25,37}$ No effect in early postmenopausal women probably can be explained by already reduced levels of $\mathrm{PTH}$, and calcitriol, as a consequence, because serum calcium levels are sufficient due to the increased bone resorption. ${ }^{38.39}$ This also might explain the reported prevention of bone loss from the lumbar spine in young women with estrogen deficiency by PTH treatment (increased calcitriol synthesis and calcium absorption). ${ }^{40}$ If bone resorption is inhibited (e.g., by hormone replacement therapy) calcium supplementation becomes more effective during this early postmenopausal period. ${ }^{41}$

The greatest benefits of calcium supplementation are reported from studies in elderly $(>70$ years of age $)^{32,42}$ and late postmenopausal women ( $>9$ years postmenopausal) $27,37,43-45$ who have moderate losses of trabecular and cortical bone of about $1 \%$ per year. In a study with Swedish postmenopausal women, ${ }^{46}$ a positive relation with BMD was found at estimated calcium intakes above $1400 \mathrm{mg}$ per day. Heaney et al. ${ }^{47}$ showed that increased milk consumption (about $700 \mathrm{mg}$ additional calcium per day) reduced bone turnover within 12 weeks. Total daily calcium consumption was about $1400 \mathrm{mg}$. The milk, however, also supplied about 200 IU vitamin D. An additional effect of vitamin $D$ on calcium supplementation is likely, especially in the case of a marginal vitamin D status. Other studies ${ }^{27,43,48-50}$ indicate that supplementation with 800 to 1250 $\mathrm{mg}$ of calcium per day is beneficial for BMD of the lumbar spine, especially during the early phase of supplementation (Figure 1). Effects on BMD of the femoral neck and total proximal femur are contradictory but might be positive in the longterm. Lower amounts of supplemented calcium (500 mg per day) are not or less effective, especially in combination with low dietary calcium intakes. $^{37,51-54}$ This suggests that the total daily calcium intake should be $\geq 1500 \mathrm{mg}$ for a positive influence on bone. In Northern Europe, however, high calcium intakes go hand in hand with a high incidence of osteoporosis. Recently, it has been suggested that this is not related to the high calcium intake but probably to excessive daily intakes (>1.5 mg) of retinol (not of pro-vitamin A carotenoids). ${ }^{55}$ It has to be considered, however, that comparison of the studies referred to is difficult because the contribution of dietary calcium intake differed from 400 to about $1000 \mathrm{mg}$ per day. Besides that, different calcium preparations were used and supplements were sometimes given in divided doses during the day, which increases daily absorption.

The above-mentioned studies indicate that a high total daily calcium intake $(\geq 1500 \mathrm{mg}$ ) seems to be important for a positive effect on bone. At the same time, however, attention has to be paid to other nutrients, such as vitamin A, which may reduce the calcium effect.

\section{VITAMIN D}

Vitamin $D$ deficiency is associated with rickets, osteoporosis, muscle weakness, and decreased immune function. ${ }^{56,57}$ Based on the serum level of calcidiol $\left(25(\mathrm{OH}) \mathrm{D}_{3}\right)$, vitamin D status has been defined as lowered $(<100 \mathrm{nmol} / \mathrm{L})$, insufficient $(25$ to $50 \mathrm{nmol} / \mathrm{L})$, or deficient $(<25 \mathrm{nmol} / \mathrm{L}) .{ }^{58}$ For healthy subjects there is no evidence of adverse effects with serum calcidiol concentrations $<140 \mathrm{nmol} / \mathrm{L}$. The highest 'natural' level obtained from sunshine was found to be $225 \mathrm{nmol} / \mathrm{L} .{ }^{59}$ Calcitriol $\left(1,25(\mathrm{OH})_{2} \mathrm{D}_{3}\right)$ is the most active metabolite of vitamin $\mathrm{D}$, and specific receptors are found in many tissues. ${ }^{56}$ The most well-known function is the support of active intestinal calcium absorption. Fatty fish, fish-liver oils (herring liver oil in particular), and liver are rich sources of vitamin $D_{3}$. Products such as milk, yogurt, margarine, and breakfast cereals are important contributors if they are fortified with vitamin D. Vitamin $\mathrm{D}_{2}$ (of vegetable origin) plays a minor role in the overall vitamin D intake. ${ }^{1,60}$ U.S. Adequate intakes ${ }^{13}$ for ages 51 to 70 and over 70 years are 400 and $600 \mathrm{IU}$ per day, respectively. However, higher dosages ( 800 to $1000 \mathrm{IU} /$ day) might be preferable for the older age group. ${ }^{59,61}$ To prevent adverse effects in the healthy adult population, the dietary intake of vitamin $\mathrm{D}$ should probably not exceed 2400 IU per day.6 Extreme intakes of vitamin D $(>10,000$ IU per day) resulted in serum calcidiol levels with considerable biological activity, which may lead to extraosseous calcifications. ${ }^{62}$ 


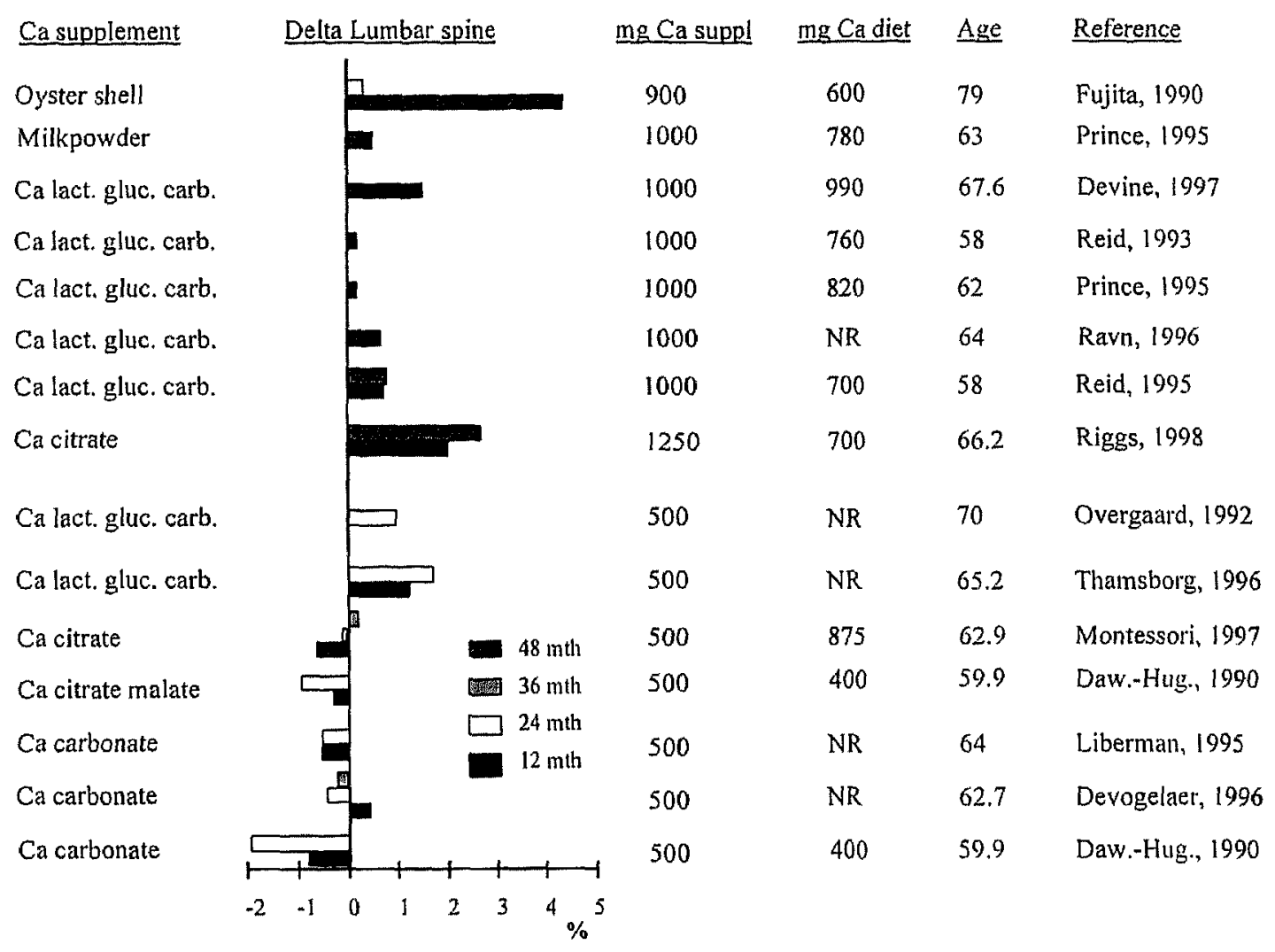

Abbreviations: Ca lact.gluc. carb., calcium lactate, -gluconate, -carbonate; suppl. supplemented; NR, not reported

FIGURE 1. Effects of calcium supplementation without additional vitamin D on BMD of the lumbar spine. Changes are presented as a percentage from baseline after $12,24,36$, or 48 months of intervention. Information is presented about the calcium source, amount of supplemented elemental calcium, the amount of dietary calcium, and the age of participants.

\section{A. Absorption and Synthesis of Vitamin $D$ and Its Metabolites}

Vitamin $\mathrm{D}$ is absorbed in the small intestine in association with dietary fat or synthesized in the skin after exposure to UV light. ${ }^{56}$ Skin-derived vitamin $\mathrm{D}_{3}$ may account for about $50 \%$ of circulating vitamin $\mathrm{D}^{63}$ and 80 to $90 \%$ of the body stores. ${ }^{60,62}$ Latitude determines when an adequate synthesis of vitamin $\mathrm{D}$ can take place. Above and below latitudes of approximately $40^{\circ} \mathrm{N}$ and $40^{\circ} \mathrm{S}$, respectively, synthesis of vitamin $D_{3}$ in the skin is absent during most of the winter months. ${ }^{13,64}$

Especially in the liver, but also in many other tissues, vitamin $\mathrm{D}$ can be converted into calcidiol. This hydroxylation is catalyzed by 25 - $\alpha$-hydroxylase. ${ }^{65}$ Although calcidiol synthesis depends primarily on the amount of circulating vitamin $D, i$ its level is maintained within the range of about 75 to
$220 \mathrm{nmol} / \mathrm{L}$ across vitamin $\mathrm{D}$ supplies from 800 to 10,000 or 20,000 IU per day. ${ }^{59}$ The synthesis of calcidiol is more effective from vitamin $\mathrm{D}_{3}$ than from $D_{2}$, which is possibly because of a higher affinity of vitamin $\mathrm{D}_{3}$ for vitamin $\mathrm{D}$ binding protein (DBP) ${ }^{66}$ Circulating calcidiol concentrations are found to be higher in men than in women, ${ }^{67}$ higher in white women than in black women, ${ }^{68}$ and seem to be inversely correlated with body mass index ${ }^{67}$ and age. ${ }^{60}$ In the kidney, calcidiol can be converted into calcitriol by $1 \alpha$-hydroxylase. Minor amounts of calcitriol may be produced in other tissues such as bone cells, monocytes, and macrophages. In circulation, the major part of calcitriol is bound to vitamin $\mathrm{D}$ binding protein. Only about $0.4 \%$ appears free or unbound in serum and is hormonally active. The synthesis of calcitriol is stimulated by PTH and phosphate and is less influenced by the amount of circulating calcidiol. ${ }^{1}$ 
Calcitriol and increased serum calcium lower serum PTH levels. ${ }^{56}$ Calcitriol also inhibits its own synthesis in the kidney by binding to the vitamin $D$ receptor (VDR) that stimulates the enzyme 24hydroxylase. This enzyme mediates the initial step in a cascade of oxidation's that ultimately results in calcitroic acid. ${ }^{69}$ The major route of excretion of vitamin D and its metabolites is in the feces. ${ }^{56}$

\section{B. Vitamin D Receptor (VDR)}

Non-genomic actions of calcitriol involve the opening of voltage-sensitive calcium channels and the activation of protein kinases, through which changes occur in intracellular calcium, phospholipid metabolism and phosphate transport, alkaline phosphatase and adenylate cyclase activities, ${ }^{1}$ and membrane fluidity. ${ }^{56}$ Some of these rapid nongenomic actions of calcitriol might be mediated by a membrane-bound VDR. ${ }^{70}$ The genomic VDR-mediated mechanism influences gene transcription. ${ }^{62}$ The expression of VDR can be up- and down-regulated by hormones and growth factors. Subtle changes in the number or genotype of VDR are expected to play a major role in changes of bone metabolism. An age-related decline in intestinal VDR creates a relative calcitriol-resistant state and impairs active calcium absorption. ${ }^{1}$ It has been suggested that polymorphism of the VDR gene may account for a substantial proportion (as much as $20 \%{ }^{71}$ ) of the heritable component of $\mathrm{BMD} .^{72}$ However, this hypothesis remains controversial, is possibly more pronounced in younger subjects, and might be true only in case of low calcium intakes. ${ }^{73}$ In Asian ethnic groups with a traditionally low calcium intake, VDR genotypes associated with a low BMD have a lower frequency compared with the Western populations, which points to a genetic selection. Aside from BMD, VDR polymorphism's might be linked to cellular proliferation, osteophyte formation, prostate cancer, hyperparathyroidism, and perhaps diabetes. ${ }^{74}$

\section{Classic Actions of Vitamin D}

The responses to calcitriol are tissue specific and depend on the state of cellular differentiation and concentration of calcitriol. This implies that effects may be opposite to each other, as has been reported for calcitonin and type 1 collagen., ${ }^{1,75}$ In Table 1 a number of calcitriol-regulated proteins are listed. The active uptake of calcium as well as the $\mathrm{Na}^{+}$-dependent uptake of phosphate is controlled by calcitriol. ${ }^{1}$ This control may be as high as $60 \%$ in case of low calcium intakes or as low as $20 \%$ at calcium intakes of about $1500 \mathrm{mg} .{ }^{64}$ Estrogens stimulate active calcium absorption by upregulation of gut VDR, ${ }^{62}$ and by increasing serum levels of DBP. ${ }^{1}$ In bone, the principal target cells for calcitriol are believed to be the osteoblasts, ${ }^{76}$ with effects being dependent on the stage of cell differentiation and calcitriol concentration. In rat and osteosarcoma cell cultures, it was found that genes of osteocalcin, alkaline phosphatase, and collagen are down-regulated in proliferating immature osteoblasts but up-regulated in mature osteoblasts. ${ }^{1,60}$ With regard to osteoclasts, calcitriol stimulates the retraction of nodule-associated osteoblasts to allow for osteoclast interaction, stimulates the differentiation of promonocytes into osteoclasts, and activates the synthesis of $\beta_{3}$ protein, which is part of the osteoclast surface marker $\alpha_{v} \beta_{3}$. Binding of this marker to the bone matrix protein osteopontin finally stimulates bone resorption. ${ }^{1}$ Some of the bone resorption stimulating effects of calcitriol may be through the upregulation of epidermal growth factor (EGF) receptors. ${ }^{77}$ It is thought that the osteoclast-mediated effects are especially stimulated in case, of high, pharmacological doses vitamin $D$ for long periods. ${ }^{75,78}$ In skeletal muscle tissue, calcitriol controls muscle contraction through a direct effect on calcium transport and may reduce instability and falls in the elderly..$^{56,79}$

In the kidney, calcitriol regulates the $1 \alpha$ - and $24-$ hydroxylases and the synthesis of calbindin D28k, a protein mediating the active calcium reabsorption. ${ }^{1}$ With age, when renal mass and function falls, including the capacity to synthesize calcitriol, ${ }^{2}$ a mild secondary hyperparathyroidism may develop to stimulate $1 \alpha$-hydroxylase (Figure 2). ${ }^{1,78}$ Vitamin $D$ deficiency, a decreased number of VDR in the parathyroid gland and estrogen deficiency can also cause hyperparathyroidism. ${ }^{1,11}$ Hyperparathyroidism not only stimulates calcitriol synthesis and, hence, intestinal calcium absorption, but also bone turnover. ${ }^{38}$ 
Table 1

Important Calcitriol-Dependent Proteins and Their Main Physiological Function in Bone Metabolism

\begin{tabular}{|c|c|c|c|c|}
\hline Protein & Origin & Function & Action of calcitriol & Reference \\
\hline PTH & Parathyroid gland & $\begin{array}{l}\text { Stimulates calcitriol synthesis } \\
\text { stimulates bone resorption }\end{array}$ & inhibition & 11 \\
\hline Calcitonin & Thyroid gland & $\begin{array}{l}\text { Inhibits osteoclasts } \\
\text { inhibits PTH }\end{array}$ & Inhibition/stimulation & 11,83 \\
\hline $1 \alpha$-hydroxylase & Kidney & Synthesis of calcitriol & Inhibition & 1 \\
\hline 24-hydroxylase & a/o. kidney & Hydroxylation of calcitriol & Stimulation & 1 \\
\hline Type I collagen & Osteoblast & Bone formation & Inhibition/stimulation & 1,75 \\
\hline Osteocalcin & Osteoblast & $\begin{array}{l}\text { Coupling of bone formation- } \\
\text { resorption }\end{array}$ & Stimulation & 1 \\
\hline Osteopontin & $\begin{array}{l}\text { Osteoblast, osteoclast, } \\
\text { osteocyte }\end{array}$ & anchors osteoclasts & Stimulation & 1 \\
\hline $\begin{array}{l}\text { Bone alkaline } \\
\text { phosphatase }\end{array}$ & Osteoblast & Mediates bone formation & Stimulation & 1 \\
\hline IGF-I receptor & Osteoblast, osteoclast & $\begin{array}{l}\text { Mediates bone formation and } \\
\text { resorption }\end{array}$ & Stimulation & 75 \\
\hline $\begin{array}{l}\text { Calcium binding } \\
\text { proteins }\end{array}$ & a/o. intestine, kidney & Transports calcium & Stimulation & 56 \\
\hline
\end{tabular}

Note: PTH, parathyroid hormone; IGF-1, insulin-like growth factor-1.

\section{Effects of Vitamin D Supplementation}

Supplementation can take place by giving either vitamin $D$ or one of its metabolites. ${ }^{75}$ Major effects of vitamin D treatment are a lowering of serum PTH levels and an increase in intestinal calcium absorption. ${ }^{30,80}$ Therefore, in early postmenopausal women vitamin D might be less effective because PTH levels are said to be already reduced because of adequate serum calcium levels. ${ }^{39}$ However, these women may develop an increased sensitivity to normal serum levels of PTH that stimulates bone turnover. Small or no effects were seen with 300 or 400 IU of vitamin $D$ per day on BMD or calcitriol synthesis in early postmenopausal women with a high calcium intake. ${ }^{81,82}$ The treatment of early postmenopausal Japanese women ${ }^{83}$ with an oral dose of $0.75 \mu \mathrm{g}$ of 1- $\alpha$-hydroxyvitamin $D_{3}$ decreased serum PTH levels and bone resorption, and slightly but signifi- cantly increased BMD of the lumbar spine. This study supports the idea that vitamin D treatment in early postmenopausal women is most effective when synthesis of calcitriol is not or less dependent on serum PTH levels. ${ }^{84}$ In the elderly, additional dietary vitamin $\mathrm{D}$ (up to $800 \mathrm{IU}$ per day) possibly prevents an important number of fractures, particular in those on a marginal calcium and vitamin D intake. ${ }^{85,86}$ In Finnish elderly with a suggested adequate intake of calcium, a single injection of 150,000 to 300,000 IU vitamin D significantly reduced all fractures. ${ }^{87} \mathrm{~A}$ reduced fracture incidence was also reported by Chevalley et al. ${ }^{42}$ after a single injection of 300,000 IU vitamin D in combination with $800 \mathrm{mg}$ calcium per day. Daily supplementation with $700 \mathrm{IU}^{88}$ and $800 \mathrm{IU}^{32}$ vitamin $\mathrm{D}$, in combination with 500 and $1200 \mathrm{mg}$ calcium, respectively, showed the same effect. Postmenopausal women with osteoporosis formed less new vertebral fractures after 2 years 


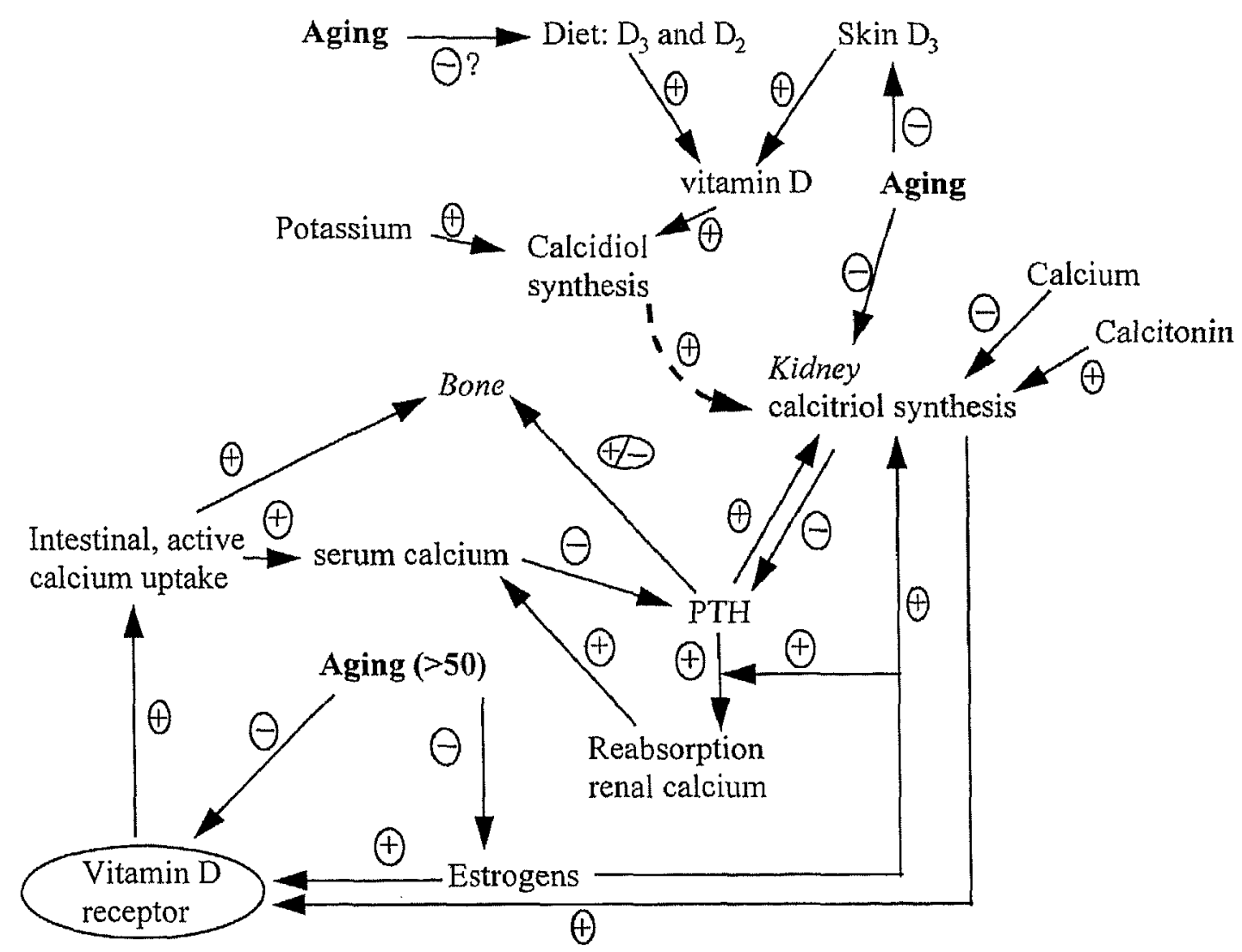

FIGURE 2. Schematic representation of the role of aging on vitamin D and PTH in bone metabolism

of intervention with daily intakes of $1000 \mathrm{mg}$ calcium and $800 \mathrm{IU}$ vitamin $\mathrm{D}_{2}$. These women, however, still lost bone from the femoral neck. ${ }^{89}$ Postmenopausal women with a low daily calcium intake of $950 \mathrm{mg}$, including $500 \mathrm{mg}$ from supplementation, combined with 700 IU vitamin D only increased BMD of the lumbar spine and the femoral neck during the first year of the study. After the second year, BMDs were below baseline values. $^{90}$ The results of a Dutch study ${ }^{86}$ were not in line with the findings of a previously mentioned French study. ${ }^{32}$ The Dutch participants, who did not show a reduction in hip fractures, differed by being relative healthy and by already having a lower incidence of hip fractures. Furthermore, they received no additional calcium, had a lower total daily calcium intake and a lower vitamin D supplementation (400 IU vs. $800 \mathrm{IU})$ compared with the French. None of these factors support a reduction in fracture incidence. In addition, the dosage of $400 \mathrm{IU}$ of vitamin $\mathrm{D}$ was reported to be ineffective in postmenopausal osteoporosis. ${ }^{75}$ In combination with estrogen therapy, 300 IU of vitamin $D_{3}$ per day had an additional positive effect on femoral neck BMD in osteoporotic women (7.1 years postmenopausal, $750 \mathrm{mg}$ calcium per day) ${ }^{84}$

The above-mentioned studies indicate that an effect of vitamin D on BMD is likely, especially in case of a marginal vitamin D status. Furthermore, for a positive effect on bone, vitamin $\mathrm{D}$ supplementation should be combined with an adequate total daily calcium intake.

\section{MAGNESIUM}

Magnesium is the fourth most abundant element in the body, about $25 \mathrm{~g}$ in total. ${ }^{19}$ Normally, $34 \%$ of total body magnesium is intracellular, $1 \%$ is extracellular, and about $65 \%$ is located in bone. ${ }^{91,92}$ Complexed with ATP, magnesium takes part in many enzyme reactions such as cAMP 
formation, phosphorylations, and in protein and nucleic acid synthesis. ${ }^{19}$ Magnesium intake is said to be marginal in the entire population, ${ }^{93}$ but deficiency is seldomly seen. For healthy adult men and women, recommended intakes ${ }^{13}$ are 420 and $320 \mathrm{mg}$ per day, respectively. Magnesium is present in most foods, in particular those of vegetable origin containing chlorophyll. ${ }^{19}$ High concentrations are found in whole seeds. Relatively poor sources are fish, meat, milk, and commonly eaten fruits, with the exception of bananas. ${ }^{94}$ The tolerable upper limit for magnesium from nonfood sources (i.e., additional magnesium) for adults is $350 \mathrm{mg}$. The first effect of excessive magnesium intake is diarrhea. ${ }^{13}$

\section{A. Intestinal Absorption and the Role of Magnesium in Bone Metabolism}

The intestinal absorption, active as well as passive, varies from 25 to $75 \%$ on high- and lowmagnesium diets, respectively. ${ }^{19}$ With increasing age, magnesium absorption decreases. In people older than 70 years of age it is about $70 \%$ of what is was at the age of 30 . This may lead to disturbances in bone, kidney, and hormone metabolism. Aside from a reduced absorption, magnesium may also be lost as a result of urinary leakage (organ function and use of diuretics), diseases, and/or their treatments. ${ }^{93}$

Five functions are suggested for magnesium in bone metabolism, affecting remodeling, strength, and preservation..$^{95-97}$ First, magnesium, which appears to be located on the crystalline surface of bone, destabilizes hydroxyapatite crystals, and prevents hydroxyapatite crystal formation. This limitation of hydroxyapatite crystal size increases bone strength. $5,98,99$ Secondly, magnesium is necessary to maintain the $\mathrm{pH}$ of extracellular fluid (ECF) somewhat higher than the $\mathrm{pH}$ of blood. In this way a barrier is formed to prevent calcium leakage from bone because of a low blood $\mathrm{pH}$. Patients with osteoporosis showed a decreased ECF $\mathrm{pH} .{ }^{95}$ Uncontrolled hydrogen ion excretion (via a $\mathrm{Na}^{+}-\mathrm{H}^{+}$exchange carriers) by osteoclasts, or insufficiently working potassium pumps of osteocytes can disturb this ECF barrier. ${ }^{100,101}$ A higher $\mathrm{pH}$ of ECF also might inhibit the resorption activ- ity of osteoclasts. ${ }^{102}$ Third, magnesium stimulates calcitonin, which inhibits osteoclasts. ${ }^{91}$ Furthermore, magnesium deficiency, intracellular depletion in particular, was found to correlate with low-serum PTH levels that may result in symptomatic hypocalcemia. ${ }^{91,92,103}$ Under these conditions, hydroxyapatite crystals may grow larger, ${ }^{98}$ active bone resorption will be impaired, and calcitriol synthesis may be decreased. The $1 \alpha$ hydroxylation of calcidiol is a magnesium-dependent and PTH stimulated reaction. ${ }^{104}$ Finally, in vitro proliferation of osteoblast-like cells was directly related to magnesium concentrations in the medium. ${ }^{92}$ Hypomagnesemia in rats resulted in a decreased trabecular bone volume, decreased osteocalcin levels, and a decreased mineral content of the newly formed metaphysis. ${ }^{99}$

\section{B. Effects of Magnesium Supplementation}

Higher intakes of dietary magnesium were associated with a higher BMD in elderly men and women in a community-based study, ${ }^{105}$ and in Japanese elderly living in Hawaii. ${ }^{106}$ In a crosssectional study with 62 healthy women ( 45 to 55 years of age) higher intakes of magnesium, and also of potassium and alcohol, were associated with higher total bone mass. ${ }^{107}$ These higher intakes of magnesium and potassium were a result of higher fruit and vegetable consumption. Mean magnesium and calcium intakes were 326 and $1101 \mathrm{mg}$ per day, respectively. In two studies with postmenopausal women, ${ }^{108,109}$ however, no associations were found between daily intakes of about $250 \mathrm{mg}$ of dietary magnesium and BMD. Two more recently published studies with postmenopausal women suggest an effect of magnesium on BMD after 2 years of supplementation but with higher daily intakes of magnesium..$^{92,110}$ In five patients with gluten-sensitive enteropathy, ${ }^{92} \mathrm{BMD}$ of the femoral neck and total proximal femur increased significantly after an intake of about $500 \mathrm{mg}$ of magnesium per day for 2 years. The increase in lumbar spine BMD was not significant. In 14 women it was shown that serum $\mathrm{PTH}$, possibly involved in the effect on BMD, rose only in magnesium-depleted subjects and not 
in subjects with an adequate magnesium status. Low-serum PTH may result in hypocalcemia and, as a consequence, may negatively affect bone metabolism. Magnesium status was assessed by the determination of serum magnesium, red blood cell and lymphocyte free magnesium, and total lymphocyte magnesium. Unfortunately, this study was not placebo controlled. In an open, controlled Israelian study with postmenopausal women ( $\mathrm{n}=$ $31),{ }^{110} \mathrm{BMD}$ of the ultra-distal radius of the forearm was significantly increased ( 1 to $8 \%$ ) after 2 years of supplementation with $250 \mathrm{mg}$ of magnesium per day. Total daily magnesium intake was about $500 \mathrm{mg}$. In untreated controls, mean bone density significantly decreased. High intakes of magnesium in combination with low dietary calcium, however, were found to be a risk factor for hip fracture. The reason for this is not clear, but an impairment of calcium absorption and stimulation of calcium excretion has been proposed. ${ }^{111}$

Despite the small number of studies performed, the small number of participants involved, and questionable study designs, a positive effect of magnesium on bone health may be suggested. Magnesium supplementation should be accompanied by an adequate supply of calcium.

\section{STRONTIUM}

Strontium is the most abundant trace element in sea water (up to $8 \mathrm{mg} / \mathrm{L}$ ), and as a consequence levels in seafood may be as high as $25 \mathrm{mg} / \mathrm{kg} .{ }^{112}$ The body store is about $350 \mathrm{mg}$, of which $99 \%$ is present in bones. ${ }^{19}$ The radioactive as well as the stable form of strontium have been found in cow's milk. The potentially dangerous radioactive strontium concentrations ${ }^{113}$ reflect environmental contamination (e.g., above-ground nuclear tests). ${ }^{114}$ Stable strontium concentrations in full cream milk have been found to range from 180 to $2800 \mu \mathrm{g} / \mathrm{L}{ }^{113}$ Other dietary sources are meat, poultry, wheat bran and the peel of root vegetables. The content in drinking water varies from 20 to $60 \mu \mathrm{g} / \mathrm{L}$, but higher values have been reported. Daily intakes are estimated to be about 1 to $3 \mathrm{mg} \cdot{ }^{19,115}$ Although the lethal doses for $50 \%$ of tested mice (LD50) for stable strontium chloride was about $5000 \mathrm{mg} / \mathrm{kg}$ of body weight, ${ }^{116}$ much lower amounts (about 76 mg per day) were found to have deleterious effects on bone in rats. ${ }^{117}$

\section{A. Absorption and Action in Bone}

The intestinal absorption of strontium and its uptake in bone mineral is discriminated in favor of calcium. ${ }^{118-120}$ In animal studies, this discrimination develops with age. ${ }^{118}$ In adults, only 20 to $40 \%$ of the ingested strontium passes through the intestinal wall. About $99 \%$ of the absorbed amount is stored in bone mineral. ${ }^{119}$ Clearance of strontium seems to be rapid. ${ }^{121}$ In animal models, positive effects on trabecular and cortical bone have been found, ${ }^{122}$ and a positive correlation was found between bone strength and strontium content. ${ }^{123}$ Strontium easily exchanges calcium on the surface (i.e., adhesion) of hydroxyapatite crystals in old and new bone, and into (i.e., substitution) the crystals of new bone. ${ }^{20,121}$ The physiological effects of adhesion or substitution, however, are different. In vitro, adhesion (up to about $25 \%$ of calcium) inhibited the dissolution of calcium hydroxyapatite and increased bending strength. In contrast, substitution (strontium substituting 10\% of calcium) resulted in a faster dissolution in water, a reduced bending strength, ${ }^{123}$ and slowed down hydroxyapatite deposition. ${ }^{124}$ High intakes of strontium may also block the biosynthesis of calcidiol into calcitriol and hence decrease the active intestinal calcium absorption. ${ }^{112}$ In monkeys, a short-term treatment with a high dosage of strontium (up to $128 \mathrm{mg} / \mathrm{kg} /$ day) during 13 weeks did not cause disturbances in bone apposition and calcification. ${ }^{121}$ In animals and in vitro a positive, direct influence of strontium on osteoblastic cells was found. ${ }^{7,125,126}$ A stimulated bone formation may cause a transitory slight decrease in serum calcium levels. ${ }^{117,127}$ In culture and in young growing animals, strontium increased levels of complexed acidic phospholipids (CPLX) that appear to play a role in initiating bone mineralization. ${ }^{101,120}$ In vitro, however, the strontium increased CPLX abolished calcium incorporation. This may be a result of decreased matrix vesicle degradation that is necessary for mineralization. ${ }^{112}$ Growing hydroxyapatite crystals, inside the matrix vesicles, finally disrupt the matrix vesicle 
wall. ${ }^{128}$ High intakes of strontium may prevent this disruption through the inhibition of hydroxyapatite crystal growth. Strontium seems to increase non-collagenous proteins of which several prevent hydroxyapatite precipitation, ${ }^{112}$ and/or because incorporation of strontium into the initial hydroxyapatite crystals impairs further proliferation. ${ }^{120}$

\section{B. Effects of Strontium Supplementation}

In the 1950 s, strontium lactate was already used to treat osteoporosis in daily doses representing $1700 \mathrm{mg}$ of strontium for periods ranging from 3 months to 3 years. ${ }^{129}$ Postmenopausal, osteoporotic women were supplemented for 2 years with about $340 \mathrm{mg}$ of strontium per day (in the form of S12911) resulting in a in a significant increase in lumbar spine BMD and a reduced number of new vertebral fractures. ${ }^{122}$ Although strontium may cause false-positive BMD increases, because it has a higher atomic number than calcium, ${ }^{124}$ an increased BMD of the lumbar spine was also found after adjustment for bone strontium content in early postmenopausal women with a daily intake of $170 \mathrm{mg}$ of strontium (S12911) and $500 \mathrm{mg}$ of calcium for 2 years. The placebo group showed a decreased BMD. ${ }^{130}$ In pain treatment, for example, caused by bone metastases and osteoporosis, not only radioactive strontium but also stable strontium has been shown to be successful. ${ }^{117,129,131}$

In vitro studies, and animal studies, indicate that strontium might have an anabolic effect on bone. In human studies positive effects on BMD are reported. However, because high intakes of strontium may impair bending strength, vitamin D metabolism and bone mineralization, chronic intakes of low amounts might be preferred.

\section{FLUORINE}

Fluorine is an essential trace element required for normal dental and skeletal development. ${ }^{132}$ However, long-term consumption ( $>10$ years) of relatively low amounts of fluorine per day $(\geq 10$ $\mathrm{mg}$ ) may lead to skeletal fluorosis. The adequate daily intake for individuals 19 years and older is $3.8 \mathrm{mg}$ and $3.1 \mathrm{mg}$ per day for males and females, respectively, with a tolerable upper level of $10 \mathrm{mg}$ per day. ${ }^{13}$ About $99 \%$ of the body fluorine is found in bone and increases with age because of a long residence time. ${ }^{56}$ At concentrations as high as $10,000 \mathrm{ppm}$, bone strength decreases by about $13 \%$ at recommended calcium intakes (1000 to $1200 \mathrm{mg}$ per day) or by as much as $45 \%$ in the case of calcium deficiency. ${ }^{132}$ The concentrations of fluorine in soil, water, and many foods vary due to soil fertilizers, pollution, and enrichment strategies. A rich source of fluorine is tea. ${ }^{13}$ High intakes of tea have been associated with fluorosis. ${ }^{133}$ In patients with renal deficiency, small doses equivalent to 3 to $10 \mathrm{mg}$ per liter of drinking water may already impair mineralization. ${ }^{134}$

\section{A. Intestinal Absorption and Action on Bone}

Fluorine is passively absorbed from the intestine, lungs, and skin. In the intestine, absorption ranges from $90 \%$ in water to 65 to $100 \%$ in food and fluoride preparations. ${ }^{1,132,135}$ Absorption is negatively affected by low gastric acid secretion and concurrent administration of calcium ${ }^{1}$ except for sodium mono-fluorphosphate. In air, hydrogen fluoride is the dominant form that is rapidly absorbed from the respiratory tract. ${ }^{132,135}$ In the body, fluorine stimulates the proliferation of preosteoblasts, ${ }^{132}$ which increases the number of osteoblasts ${ }^{136}$ without affecting bone resorption. A stimulation of osteoblastic activity leads to overfilling of resorption cavities, increasing trabeculae thickness and bone volume. ${ }^{1}$ Vitamin D supplementation seems to be necessary to blunt the increase in osteoid thickness, stimulating a proper mineralization. There is no evidence that fluorine supplementation will lead to the formation of new trabeculae at an older age. ${ }^{137}$ The action on preosteoblasts is mediated by one or more growth factors such as insulin-like growth factor I (IGF-I) and transforming growth factor- $\beta$ (TGF $\beta$ ). ${ }^{1}$ It also has been suggested that, due to fluoride treatment, flat lining cells dedifferentiate into osteoblasts or become replaced by new osteoblasts, bypassing the normal sequence of remodeling. ${ }^{137}$ Theoretically, active fasting serum 
fluorine levels, substantiated by increased BMD in fluoride-treated patients to stimulate osteoblasts ranges from 5 to $15 \mu \mathrm{mol} / \mathrm{L}$. ${ }^{1,132}$ Such levels have been recorded at an intake of $26.4 \mathrm{mg}$ of fluorine per day. ${ }^{138}$ Proposed cellular mechanisms are based on the $G$ protein (guanyl nucleotide-binding proteins) hypothesis and the tyrosine phosphatase hypothesis. ${ }^{139}$ In the $\mathrm{G}$ protein hypothesis, fluorine activates a heterotrimeric $\mathrm{G}$ protein, probably by interaction with GDP to form a GTP-like molecule. Activation of GTP-binding proteins may stimulate protein kinase $\mathrm{C}$, which subsequently leads to cell proliferation. ${ }^{1,79,139}$ The tyrosine phosphatase hypothesis is based on inhibition of phosphotyrosyl protein phosphatase (PTPP) by fluorine (Figure 3). ${ }^{1}$ Due to the inhibition of PTPP, activation of a receptor tyrosine-kinase ${ }^{140}$ by growth factor binding such as IGF-I or TGF $\beta$ leads to a cascade of phosphorylations, DNA synthesis, and finally to cell proliferation. Evidence for the PTPP route is the blocking of the mitogenic effect of fluorine by the phytoestrogen genistein found in soybean, which is a tyrosyl kinase inhibitor. ${ }^{1}$ Extracellularly, the incorporation of fluorine (substituting hydroxyl ions) in bone, particularly in newly formed trabecular bone, results in the formation of fluoroapatite crystals, which are less soluble and larger than the hydroxyapatite crystals., 141,142 Larger crystals predict an increased compressive strength, but a reduced bending strength, which might explain a reported increase in crystal brittleness. ${ }^{1}$

\section{B. Effects of Fluoride Supplementation}

Fluoride in dosages of 50 to $75 \mathrm{mg}$ sodium fluoride ( 26.4 to $33.9 \mathrm{mg}$ of fluorine) per day increased calcium balance, ${ }^{100}$ bone mineralization, and in vitro collagen production. ${ }^{141}$ Positive effects on BMD are especially seen in the axial skeleton and may last for as long as 6 years. ${ }^{1}$ Other sites, for example, hip and forearm, might be positively or negatively affected depending on concentrations of fluorine and calcium. Calcium may become marginal as a result of increased bone formation..$^{1,136,138}$ Effects on fracture prevention are not clear. Treatment with about $40 \mathrm{mg}$ of fluorine per day increased the rate of appendicular fractures and microfractures. ${ }^{143}$ A fluoridation strategy of drinking water (1 ppm) in Germany over a period of 30 years, however, was associated with a reduced number of hip fractures in the very old. ${ }^{144}$ A number of studies ${ }^{89,136-138,145}$ have been performed in people with osteoporosis using 20 to about $26 \mathrm{mg}$ of fluorine per day with additional calcium supplementation of 400 and 1000 mg. After study periods ranging from 12 to 48 months, increases in lumbar spine BMD of 10 to $24 \%$ were found. In late postmenopausal women with ${ }^{146}$ or without ${ }^{147}$ osteoporosis, supplementation with $1000 \mathrm{mg}$ of calcium in combination with 11.2 and $13.5 \mathrm{mg}$ of fluorine, respectively, increased BMD of the lumbar spine with 12.6 and $17 \%$, respectively, during study periods of 3 years. Three of the previously mentioned studies with a duration of 36 or 48 months also reported increases in BMD of the femoral neck, ${ }^{138,146}$ Ward's triangle and greater trochanter, ${ }^{146}$ and total hip. ${ }^{145}$ Only in the low-dose study ${ }^{146}$ were the increases in BMD of the hip significantly different from calcium supplementation alone. Furthermore, all three studies showed a decrease in spinal fracture rate. It has been suggested that the loss of cancelous bone microarchitecture before treatment might explain the low or absence of reduction in fracture risk in other studies. ${ }^{89}$ No differences were found between continuous and intermittent administration of the same total amount of fluorine. Biopsies indicate that the incidence of osteomalacia was related to fluoride dosage (26 and $34 \mathrm{mg}$ of fluorine), but could, at least in part, be overcome by additional vitamin $D$ supplementation. ${ }^{137}$ The use of slow release fluorine may have advantages, as it avoids a sharp increase in serum fluorine that may result in unwanted side effects. ${ }^{1}$

Treatment of postmenopausal women with high doses of fluorine (about $25 \mathrm{mg}$ per day) may strongly increase BMD, especially of the lumbar spine, but may also increase brittleness of bone. Lower doses of fluoride (about $10 \mathrm{mg}$ per day) showed a reduction of spinal fracture incidence. An adequate intake of calcium and vitamin D is necessary.

\section{BORON}

Boron may have a function in the maintenance of bone health, especially in the case of 


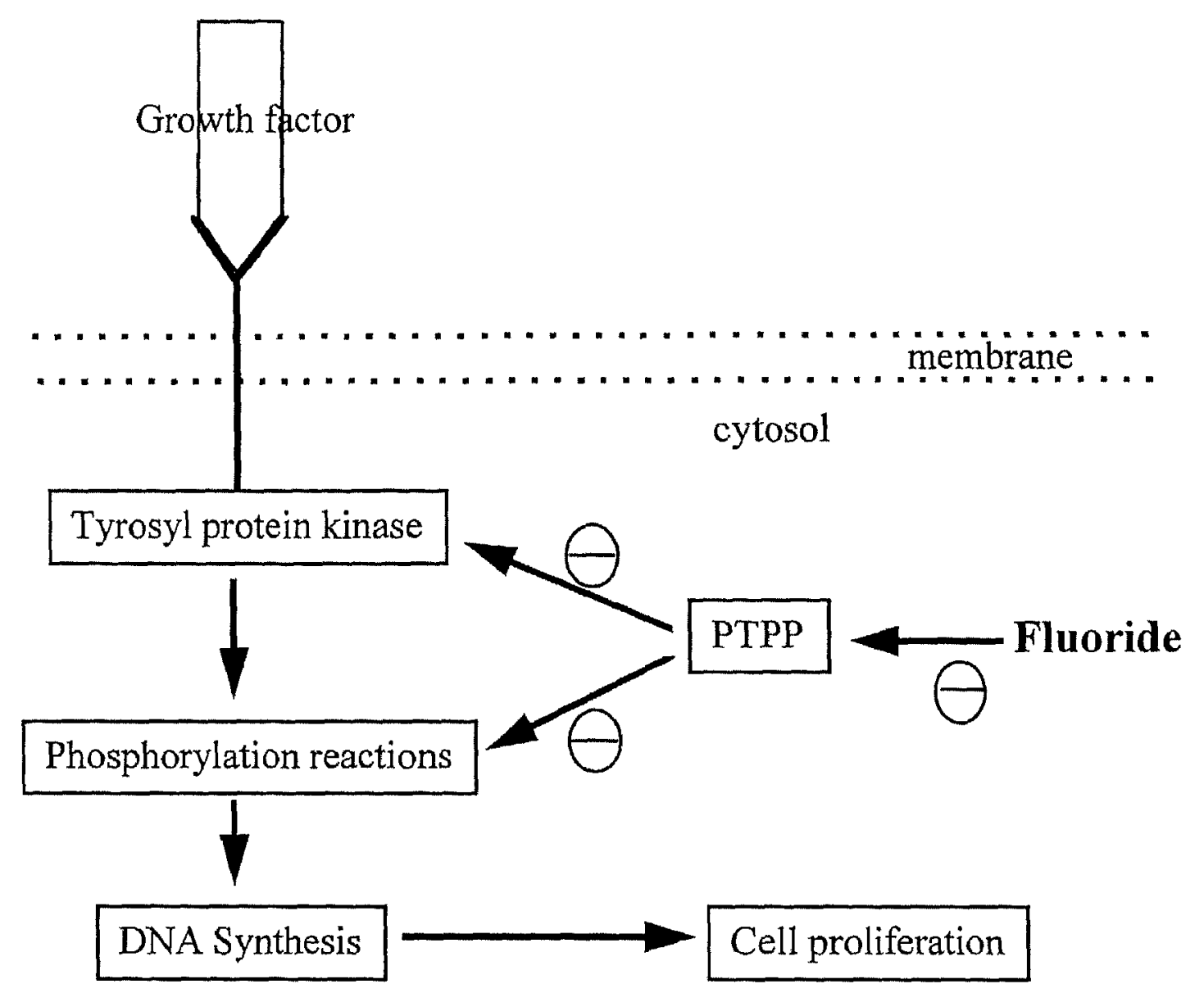

Abbreviation: PTPP, phosphotyrosyl protein phosphatase

FIGURE 3. Schematic and simplified representation of the suggested role of fluorine in the proliferation of preosteoblasts after activation of the receptor tyrosine-kinase by growth factor binding.

deficiencies of vitamin $\mathrm{D}$, magnesium, and potassium. ${ }^{8}, 148$ Other positive activities may be present in the field of heart disease and stroke, glucoserelated disorders, brain alertness, and aging. ${ }^{149}$ When there is no nutritional or metabolic stress, the need for boron seems to be low. ${ }^{50}$ A level of about $1 \mathrm{mg}$ per day has been suggested. Intakes of 3 to $4 \mathrm{~g}$ of boron for adults and $1 \mathrm{~g}$ for infants are thought to be toxic. ${ }^{149}$ Tissues affected by boron deprivation are the skeleton, kidney, and brain. ${ }^{151}$ Good sources of boron are fruits, ${ }^{152}$ vegetables, ${ }^{149}$ nuts, ${ }^{153}$ and eggs. Particularly rich sources are wine, raisins, dried parsley, and caviar (with boric acid as preservative). ${ }^{149}$ Cow's milk may contain boron in a wide range of 20 to $1000 \mu \mathrm{g} / \mathrm{L}$, which is considered to reflect the amount in the diet. ${ }^{152,154}$ Daily average intakes were calculated to range from 0.3 to $41 \mathrm{mg}$ per day, ${ }^{149}$ but perhaps a more realistic reported range is 0.5 to $3.1 \mathrm{mg}$ of boron per day. ${ }^{155,156}$ The wide range in estimated intakes can be explained by differences in methods of analysis, and a high variability in the natural distribution of boron. ${ }^{149}$

\section{A. Intestinal Absorption and Action on Bone and Bone Tissue}

Boron is rapidly and efficiently absorbed. ${ }^{155}$ Several animal studies (rats, mice, and pigs) have shown that boron supplementation ( 3 to $12 \mathrm{mg} / \mathrm{kg}$ diet or per $\mathrm{kg}$ body weight) influenced metabolism and functional properties of bone in combination with calcium- and magnesium-deficient 
diets. ${ }^{157,158}$ Different effects were seen on the femur and vertebrae, being often positive for the latter (increased compression load) but negative for the former (thinner femur wall, diminished bone, and osteoid mass). A high boron intake (350 $\mathrm{mg} / \mathrm{L}$ of drinking water) reduced osteoblastic activity in rats. ${ }^{158}$ Boron supplementation ( $3 \mathrm{mg} /$ day) increased serum concentrations of $17 \beta$ estradiol and testosterone in postmenopausal women ${ }^{159}$ possibly by changing the rate or pathway for the catabolism and excretion of these hormones. ${ }^{8}$ This effect was especially present in women with a low magnesium status. ${ }^{159}$ Some findings suggest that boron enhances ${ }^{149}$ the formation of active or hydroxylated forms of some specific steroid or steroid-related hormones (e.g., the hydroxylated form of vitamin D). ${ }^{154}$ Furthermore, boron may have a regulatory role in maintaining proper cell membrane function (e.g., transmembrane signaling) or stability. ${ }^{151}$ It seems that boron supplementation leads to an accumulation of boron in bone but not in soft tissue, whereas a high percentage of the absorbed boron is rapidly excreted in urine. ${ }^{8,152}$

\section{B. Effects of Boron Supplementation}

Boron has been reported to have an antiarthritic effect at intakes of 3 to $10 \mathrm{mg}$ per day, possibly through stimulation of the synthesis of corticosteroids. ${ }^{149,160}$ A protective role for boron in postmenopausal bone loss is suggested. Nielsen et al. ${ }^{159}$ studied 12 healthy postmenopausal women in a metabolic unit who received a supplement of 3 $\mathrm{mg}$ of boron after a 17-week period of low-boron diet $(0.25 \mathrm{mg})$. Following boron supplementation, a decreased calcium $(0.13$ to $0.09 \mathrm{~g} / \mathrm{d})$ and magnesium $(0.11$ to $0.06 \mathrm{~g} / \mathrm{d})$ excretion was found in $24-\mathrm{h}$ urine collections, within 8 days. Furthermore, these women showed a significant increase in plasma estradiol ( 21.1 to $41.4 \mathrm{pg} / \mathrm{ml})$ and testosterone $(0.31$ to $0.83 \mathrm{ng} / \mathrm{ml}$ ) concentrations. The effects were smaller in seven women consuming $315 \mathrm{mg}$ magnesium per day, compared with five women taking $115 \mathrm{mg}$ magnesium per day. In a follow-up study with four postmenopausal women, on a low magnesium diet, effects of boron supplementation on parameters of calcium metabolism were comparable with effects seen on estrogen therapy (lower serum calcitonin and increased plasma ionized calcium). ${ }^{148}$ Based on these findings, the authors suggest that boron may aid in the prevention of agerelated bone loss, as estrogen therapy is known to be beneficial for bone. ${ }^{148}$ However, the boron effects were not confirmed by Beattie and Peace. ${ }^{8}$ In their study, six women, in a metabolic unit, received a boron supplement ( $3 \mathrm{mg} /$ day) in addition to a low-boron diet. Total daily boron intake was $3.33 \mathrm{mg} /$ day. In 24-h urine collections, excretion of calcium and magnesium increased during the boron depletion period but was not restored during boron supplementation. No effects were found on the urinary excretion of deoxypyridinoline, or on plasma estradiol and testosterone concentrations. Compared with the former studies, participants in the study of Beattie and Peace had lower baseline serum estradiol concentrations (range 2 to $11 \mathrm{pg} /$ $\mathrm{ml}$ ), a daily intake of about $300 \mathrm{mg}$ magnesium (possibly even higher), and a shorter boron depletion period ( 3 vs. 17 weeks). A period of more than 21 days may be necessary to induce detectable effects of boron depletion. ${ }^{161}$ In healthy male subjects, however, plasma estradiol concentrations increased significantly after daily supplementation with $10 \mathrm{mg}$ boron for 4 weeks, without a preceding boron depletion period. ${ }^{162}$ The habitual boron intake ranged from 0.35 to $3.53 \mathrm{mg} /$ day. The higher intake of magnesium in the study of Beattie and Peace may have blunted the effect of boron especially ${ }^{163}$ and may explain the absence of a reducing effect on calcium excretion. A daily intake of about $300 \mathrm{mg}$ of magnesium combined with boron supplementation was found to increase urinary calcium loss in postmenopausal women at a later date. ${ }^{153}$ Clinical observations suggest that boron supplements accelerate the healing of broken bones. ${ }^{160}$

In postmenopausal women, additional boron (about $3 \mathrm{mg}$ per day) may have a positive influence on bone through stimulation of gonadal hormones synthesis. However, evidence is weak, and positive effects are especially seen in combination with deficiencies of vitamin $D$ and magnesium.

\section{VITAMIN K}

Compounds with vitamin $\mathrm{K}$ activity contain the 2-methyl-1,4-napthoquinone nucleus with a lipophilic side chain at position $3 .{ }^{155}$ Three types 
of vitamin $\mathrm{K}$ are known, vitamin $\mathrm{K}_{1}$ or phylloquinone, vitamin $\mathrm{K}_{2}$ series or menaquinones (called MK-4 up to MK-13), and menadione (formerly vitamin $\left.\mathrm{K}_{3}\right) .^{19,164}$ The latter may be toxic, as it can combine with sulfydryl groups in membranes. ${ }^{155}$ Vitamins $\mathrm{K}_{1}$ and $\mathrm{K}_{2}$ have a much lower toxicity. ${ }^{56}$ Vitamin $\mathrm{K}_{1}$ is present in dark, leafy green vegetables ( 40 to $50 \%$ of total intake ${ }^{165}$ ), fruit, and vegetable oils. ${ }^{166}$ Amounts in dairy products and grains may vary from 2 to $70 \mu \mathrm{g} / \mathrm{kg}$. ${ }^{164}$ Vitamin $\mathrm{K}_{2}$, estimated to contribute 10 to $30 \%$ to daily vitamin $\mathrm{K}$ requirement, ${ }^{155}$ is found in fermented dairy and soy products and is synthesized by the intestinal microflora. ${ }^{86,165}$ Moderate amounts are found in fish, meat, liver, and eggs. ${ }^{86,164}$ The dietary intake of vitamin $\mathrm{K}$, as well as the circulating levels (expressed as a ratio to triglyceride), decrease with age. ${ }^{164,165}$ It is of interest to know that vitamin $\mathrm{K}$ might be an important inhibitor of the aging of the nervous system. ${ }^{167}$ High losses (40 to $60 \%$ in feces) and low body stores (50 to $100 \mu \mathrm{g}$ ) emphasize the need for a daily supply of vitamin $\mathrm{K} .{ }^{155,166}$ Based on markers of bone formation and on BMD, it is suggested that vitamin $\mathrm{K}$ intakes should be much higher than the current recommendations $(80 \mu \mathrm{g}$ for men and $65 \mu \mathrm{g}$ for women, US RDA 1989). ${ }^{168}$ In The Netherlands, the daily intake of vitamin $K_{1}$, by subjects 55 to 70 years of age, was found to be about $250 \mu \mathrm{g}$ per day. ${ }^{169}$

\section{A. Intestinal Absorption and Action on Bone}

Intestinal absorption of vitamin $\mathrm{K}_{1}$ along with dietary fat occurs with an efficiency of 40 to $80 \% .{ }^{170}$ Supplemented vitamin $\mathrm{K}$ has a high absorbability. ${ }^{171}$ Vitamin $K_{1}$ absorption from the natural food matrix is low, absorption from green vegetables was found to be 5 to $15 \% .{ }^{172}$ Vitamin $\mathrm{K}_{2}$ derived from the intestinal microflora possibly is absorbed in the terminal ileum along with the reabsorption of bile salts. Long MKs are poorly absorbed.60,166 After absorption, vitamin $\mathrm{K}_{1}$ is transported in chylomicrons to target tissues and the liver. ${ }^{164}$ Chylomicrons (and thus vitamin $\mathrm{K}$ ) are cleared by the liver and bone marrow. Dependent on the genetic variant of the apoE, this clearance rate is higher or lower (apoE4>apoE3>apoE2). ${ }^{173,174} \mathrm{~A}$ part of the vitamin $K_{1}$ might be delivered to extrahepatic tissues via low-density lipoprotein. ${ }^{174}$ Liver stores of vitamin $\mathrm{K}$, for about $90 \%$ consisting of MK-7 to MK-13, are relatively small. ${ }^{166,175}$ The dominant form in bone is vitamin $\mathrm{K}_{1}{ }^{173}$

Vitamin $\mathrm{K}$ is an essential co-factor in posttranslational carboxylation, transforming specific glutamate residues (Glu) into $\gamma$-carboxyglutamic acid (Gla). Gla residues increase the affinity of proteins for calcium. ${ }^{176}$ Deficiency or antagonism of vitamin $\mathrm{K}$ (e.g., by coumarin derivatives, ${ }^{175}$ or vitamin $\mathrm{A}$ and $\mathrm{E}$ in pharmacological doses ${ }^{56,155}$ ) results in undercarboxylation of the specific proteins. Matrix Gla protein, protein S, nephrocalcin, and osteocalcin are vitamin K-dependent proteins involved in bone metabolism. ${ }^{177}$ Matrix Gla protein, synthesized in osteoblasts and most soft tissues, is stimulated by calcitriol, ${ }^{164,177}$ and does not react with hydroxyapatite. ${ }^{155}$ This protein appears earlier than osteocalcin, possibly preventing calcification of arteries and cartilage. ${ }^{177,178}$ Protein $S$ is produced by osteoblasts, hepatocytes, megakaryocytes, and endothelial cells. Based on reported osteopenia and vertebral body compression fractures in the case of protein $S$ deficiency, a role in bone metabolism is suggested. ${ }^{164,179}$ Nephrocalcin probably was involved in a reduction of urinary calcium loss in a group of 'fast calcium losing' postmenopausal women. No effect was seen in 'normal' or 'slow' losers. ${ }^{179}$ Osteocalcin is the most well-known vitamin $\mathrm{K}$-dependent protein in bone metabolism, synthesized by osteoblasts and osteocytes (particularly newly embedded osteocytes). ${ }^{176}$ Carboxylated osteocalcin with three Gla residues has a high affinity for hydroxyapatite, and as a consequence inhibits hydroxyapatite formation. ${ }^{155}$ In this way, carboxylated osteocalcin seems to be a regulator of bone formation, possibly by stimulating a proper, slow mineral maturation, and by preventing an excessive mineralization. ${ }^{176,180,181}$ Plasma carboxylated osteocalcin concentrations arise from new cellular synthesis, rather than from resorption or release from bone matrix. That is why osteocalcin is used as a marker of osteoblast activity. ${ }^{176}$ The C-terminal domain of osteocalcin, however, has chemotactic properties for osteoclast progenitor cells (monocytes), which suggests also a role in bone resorption. ${ }^{77.175,176}$ In osteocalcin-free 
mutant mice, bone resorption, or osteoclast function, was not altered. ${ }^{180}$ However, in combination with estrogen deficiency, osteocalcin-free mice developed more severe osteoporosis than normal ovariectomized wild-type mice. ${ }^{60,180}$ In human, the concentration of undercarboxylated osteocalcin in serum, or its ratio with carboxylated osteocalcin, seems to be a sensitive indicator for bone pathology ${ }^{182,183}$ and a predictor of fracture risk. ${ }^{177,184} \mathrm{In}$ postmenopausal women, 1 to 10 years past menopause, undercarboxylated osteocalcin was correlated with lower BMD of Ward's triangle and femoral neck in particular. ${ }^{185}$ From a prospective study in women, an inverse association between dietary vitamin $\mathrm{K}$ and the risk of hip fractures was observed. ${ }^{186}$ The percentage of carboxylated osteocalcin from total osteocalcin was found to range from 70 to $80 \%$ in young, healthy adults. In postmenopausal women this percentage was decreased to $60 \%$ or less. ${ }^{178,187}$ Other reported vita$\min \mathrm{K}$ antiosteoporotic activities are the inhibition of interleukin- 6 by vitamin $\mathrm{K}_{1}, \mathrm{~K}_{2}$, and menadione in vitro, ${ }^{188}$ and inhibition of osteoclast formation and stimulation of their apoptosis specifically by MK-4. ${ }^{60,164}$

\section{B. Effects of Vitamin K Supplementation}

In postmenopausal women with fractures of the distal radius, the percentage of carboxylated osteocalcin rose from 56.1 to $74.8 \%$, after a daily intake of $1 \mathrm{mg}$ of vitamin $\mathrm{K}_{1}$ for only 2 weeks. ${ }^{189}$ In another group of postmenopausal women, carboxylated osteocalcin was correlated with alkaline bone phosphatase, whereas undercarboxylated osteocalcin was correlated with urinary calcium excretion after 3 months of treatment with $1 \mathrm{mg}$ of vitamin $\mathrm{K}$ per day. ${ }^{183}$ Treatment of postmenopausal women, who were high calcium losers, with $1 \mathrm{mg}$ of vitamin $\mathrm{K}_{1}$ per day for 2 weeks, reduced urinary excretion of calcium and hydroxyproline by 10 to $50 \% .^{187}$ In young, healthy subjects ( 20 to 40 years of age) and in older subjects (60 to 80 years of age), an increase in the daily intake of vitamin $\mathrm{K}$ during 5 days from 100 to 420 $\mu \mathrm{g}$, reduced the undercarboxylated fraction of osteocalcin by about $40 \% .{ }^{190,191}$ MK-4, synthesized from menadione or $\mathrm{K}_{1},{ }^{60}$ in large doses (45 $\mathrm{mg} / \mathrm{d}$ ) was found to have a significant therapeutic effect on involutional osteoporosis. ${ }^{192}$ The same dose of MK-4 (45 mg/day) was effective in 54 vitamin $\mathrm{D}$ - and vitamin $\mathrm{K}$-deficient stroke patients. After 12 months of treatment, their BMD of the second metacarpal on hemiplegic sides increased with $4.3 \% \pm 9.9 \%$, whereas the loss in BMD on the intact side was smaller compared with the untreated group. ${ }^{193}$

The role of vitamin $\mathrm{K}$ in bone is not yet resolved, but a bone health-stimulating effect is suggested. The percent carboxylated osteocalcin from total osteocalcin may be used as a sensitive marker for vitamin $\mathrm{K}$ status.

\section{VITAMIN C}

Vitamin C (ascorbic acid) is a simple sugar and powerful reducing agent synthesized from glucose in many plant and animal tissues, but not in humans. Enzyme reactions that require vitamin $\mathrm{C}$ include those involved in the synthesis of hydroxyproline and hydroxylysine, and the amidation of calcitonin..$^{19,103}$ Of the fresh fruit and juices, black currant, guavas, Hawthorn berries, acerola, and rose hips are particularly rich in vitamin $\mathrm{C}$. Other important sources are leafy, green vegetables. ${ }^{19}$ The daily recommended amount of vitamin $\mathrm{C}$ is $60 \mathrm{mg}$ for those older than 50 years of age, ${ }^{94}$ however, this will probably increase to levels of 100 to $200 \mathrm{mg} /$ day. Although intakes higher than $1000 \mathrm{mg}$ of ascorbic acid do not seem to cause toxic symptoms, routine use of such large doses is not recommended. ${ }^{103}$

\section{A. Action on Bone Metabolism}

Vitamin $\mathrm{C}$ is well absorbed, $>80 \%$ at low doses $(60 \mathrm{mg})$, by passive and active transport mechanisms particularly in the small intestine. The body pool has been calculated to be greater than $1400 \mathrm{mg}$ in healthy male adults, with a turnover rate of 45 to $60 \mathrm{mg} /$ day. ${ }^{56}$ Osteoblasts contain a specific saturable, stereo-selective (low uptake of D-isoascorbic acid) transport system for vitamin $\mathrm{C}^{194}$ which is probably $\mathrm{Na}^{+}$gradient dependent. ${ }^{195}$ The maximum capacity of the $\mathrm{Na}^{+}$- 
dependent transporter is within the range of normal serum levels of vitamin $C$ of about 10 to 100 $\mu M / \mathrm{L} .{ }^{196}$ These levels can be achieved with intakes of 40 to $1000 \mathrm{mg}$ of vitamin C per day. ${ }^{155}$ Therefore, higher dietary intakes would not have much effect on uptake into tissues that produce collagen. ${ }^{196}$ It seems that vitamin $\mathrm{C}$ increases hydroxylation (by prolyl- and lysylhydroxylase ${ }^{19}$ ) of procollagen approximately fivefold, ${ }^{194}$ This is an important stimulus for an increased translation and transcription of pro-collagen mRNA. Furthermore, vitamin $\mathrm{C}$ stimulates osteoblasts to produce osteocalcin and alkaline phosphatase, and to lay down bone matrix. ${ }^{194,196}$ Bacterial lipopolysaccharides, which activate the antimicrobial complement system, have been reported to inhibit vita$\min C$ transport into the osteoblast. This inhibition by complement may, in part, explain the defects in bone repair associated with inflammatory bone diseases such as periodontitis. ${ }^{195}$ Urinary excretion of vitamin $\mathrm{C}$, as free ascorbic acid or as oxalate, occurs when the plasma concentration exceeds $70 \mu M / L$. A high excretion of oxalate may cause the development of oxalate stones. ${ }^{19}$

\section{B. Vitamin C and BMD}

In healthy premenopausal women the intake of vitamin $\mathrm{C}(126 \pm 96 \mathrm{mg} /$ day, range 16 to 1164 $\mathrm{mg}$ ) has been positively correlated with BMD of the lumbar spine, the greatest effects were seen with moderate (second and third quartiles of) vitamin C intakes. ${ }^{6}$ In postmenopausal MexicanAmerican and Caucasian-American women, a positive association was found between dietary vitamin $\mathrm{C}$ and femoral neck BMD. ${ }^{197,198}$ In the Caucasian women, the association of vitamin $\mathrm{C}$ with BMD was stronger when diets were higher in calcium ( $>500 \mathrm{mg} /$ day). ${ }^{198}$ This agrees with other studies that link vitamin $C$ with a lower risk for hip fracture. ${ }^{197}$ An association between dietary vitamin $\mathrm{C}(113 \mathrm{mg} / \mathrm{day})$ and $\mathrm{BMD}$ of the hip was not found in another U.S. study ${ }^{199}$ of postmenopausal women. However, long-term use of vitamin $\mathrm{C}$ supplements (mean total intake of $407 \mathrm{mg}$ of vitamin C per day) was associated in this group with higher BMD of the hip, especially in those participants who never used estro- gen preparations and only in women 55 to 64 years of age.

These studies suggest a positive role of vitamin $C$ in the prevention of postmenopausal bone loss in moderate amounts, ${ }^{6}$ but that are higher than the amounts currently recommended. ${ }^{199}$

\section{DISCUSSION}

A high peak bone mass after adolescence provides a profitable starting point at the moment bone mass is lost because of aging and menopause. Following menopause, an adequate intake of a number of nutrients will delay or prevent natural bone loss (Table 2). The basic element is calcium. Small differences in absorption between several calcium sources do not play an important role. The problem of a lower gastric acid secretion in older women can be overcome by supplementing with liquid calcium citrate, ${ }^{200}$ but also by supplying calcium supplements together with the meal. ${ }^{201}$ Problems with the inhibition of other ingredients in the meal are, except for iron, not to be expected. Frequently ingesting smaller amounts of calcium are preferred over a single dosage because the efficiency of absorption increases. The effects of calcium supplementation in early postmenopausal women is moderate but nevertheless useful because marginal or low calcium intakes are prevented, and estrogen and calcitonin therapies are improved. ${ }^{41}$ In late postmenopausal women and in the elderly, calcium supplementation to a total daily calcium intake of at least 1500 mg seems to increase BMD of the spine in particular, and can reduce the number of fractures. ${ }^{42,43,202}$

Fracture reduction is also suggested from vitamin D studies with older women, ${ }^{86,87}$ especially in combination with a sufficient calcium intake. ${ }^{32}$ Prevention strategies and long-term use indicate that effective additional amounts are in the range of 400 to 800 IU of vitamin D per day. Appropriate intakes should lead to serum calcidiol levels of about $100 \mathrm{nmol} / \mathrm{L} .^{59}$ Early postmenopausal women are not very sensitive to vitamin $D$ therapy. A declined setpoint for bone mass as a result of estrogen deficiency causes an increased loss of bone, as a consequence sufficient serum calcium 
Table 2

Suggested Additional Intakes for Postmenopausal Women and Major Actions on Bone of Calcium, Magnesium, Strontium, Boron, Fluoride, and the Vitamins C, D, and K

\begin{tabular}{|c|c|c|c|}
\hline Component & $\begin{array}{l}\text { Suggested } \\
\text { additional } \\
\text { daily } \\
\text { intake }\end{array}$ & Action on bone & Action through \\
\hline Calcium & $400-800 \mathrm{mg}$ & Reduction of bone turnover & Lowering of PTH \\
\hline Magnesium & $100-200 \mathrm{mg}$ & $\begin{array}{l}\text { Bone strength } \\
\text { Bone preservation } \\
\text { Reduction of bone resorption } \\
\text { Stimulation of bone formation } \\
\text { Reduction of bone turnover }\end{array}$ & $\begin{array}{l}\text { Limited HA crystal size } \\
\text { Higher pH ECF } \\
\text { Stimulation calcitonin } \\
\text { Proliferation osteoblasts } \\
\text { Synthesis of calcitriol, decreased } \\
\text { PTH secretion }\end{array}$ \\
\hline Strontium & $1-3 \mathrm{mg}$ & $\begin{array}{l}\text { Bone preservation } \\
\text { Stimulation of bone formation } \\
\text { Pain reduction }\end{array}$ & $\begin{array}{l}\text { Decreased solubility of HA crystals } \\
\text { Stimulation of osteoblasts }\end{array}$ \\
\hline Boron & Up to $3 \mathrm{mg}$ & $\begin{array}{l}\text { Reduction of bone resorption } \\
\text { and turnover } \\
\text { Antiarthritic effect }\end{array}$ & $\begin{array}{l}\text { Stimulation gonadal hormones } \\
\text { Synthesis of corticosteroids }\end{array}$ \\
\hline Fluorine & $2-4 \mathrm{mg}$ & $\begin{array}{l}\text { Bone preservation } \\
\text { Stimulation of bone formation }\end{array}$ & $\begin{array}{l}\text { Decreased solubility of HA crystals } \\
\text { Proliferation of pre-osteoblasts, } \\
\text { differentiation of flat lining cells }\end{array}$ \\
\hline Vitamin D & $200-400 \mathrm{IU}$ & $\begin{array}{l}\text { Reduction of bone turnover } \\
\text { Stimulation of bone formation } \\
\text { Stimulation of bone resorption } \\
\text { Calcium absomtion/reabsorption } \\
\text { Stimulation of skeletal muscle }\end{array}$ & $\begin{array}{l}\text { Lowering of PTH } \\
\text { Stimulation mature osteoblasts, } \\
\text { stimulation of Gla protein } \\
\text { Formation of osteoclasts, } \\
\text { anchoring of osteoclasts } \\
\text { Regulation of calcium binding } \\
\text { proteins } \\
\text { Cellular calcium transport }\end{array}$ \\
\hline Vitamin $\mathrm{K}$ & $80 \mu \mathrm{g}$ & $\begin{array}{l}\text { Stimulation of bone formation } \\
\text { Bone preservation } \\
\text { Reduction of bone turnover }\end{array}$ & $\begin{array}{l}\text { Carboxylation of osteocalcin } \\
\text { Inhibition of interleukin- } 6 \\
\text { Carboxylation of nephrocalcin }\end{array}$ \\
\hline Vitamin C & Up to $100 \mathrm{mg}$ & Stimulation of bone formation & $\begin{array}{l}\text { Collagen synthesis, stimulation of } \\
\text { osteocalcin and bone alkaline } \\
\text { phosphatase }\end{array}$ \\
\hline
\end{tabular}

Note: HA, hydroxyapatite; ECF, extracellular fluid; PTH, parathyroid hormone.

a Suggested intakes in relation to postmenopausal bone metabolism. It is assumed that intakes from normal nutrition are in line with or close to recommendations, or estimated safe intakes, of the US RDA or DRI ${ }^{13,94}$ or agree with estimated intakes (boron and strontium) as reported from healthy populations. 
levels, and a decreased need for calcitriol synthesis. ${ }^{1.38}$ Only treatment with ready-to-use vitamin $D$ metabolites seems to be effective at this stage of life.

The role of magnesium in bone health seems to be underestimated, because five suggested functions of magnesium stimulate bone strength, bone preservation, and possible bone formation. The effects of magnesium on blood $\mathrm{pH}$ are highest about 4 hours after intake, which makes extra magnesium in the evening most effective because ECF $\mathrm{pH}$ is lowest at night. ${ }^{203}$ Another beneficial effect of magnesium is the inhibition of soft tissue calcification, ${ }^{95}$ which is suggested to be positive for the cardiovascular system, especially in cases of high-calcium diets. ${ }^{155}$

Strontium might be a very interesting element with anabolic effects on bone through stimulation of osteoblasts and inhibition of osteoclasts. The effective amounts, however, are not clear. Although high amounts (e.g., $170 \mathrm{mg}$ per day) showed positive effects on BMD, ${ }^{204}$ incorporation of strontium into hydroxyapatite crystals, which is a long-term effect, may lead to a reduced bending strength, a higher solubility, and probably a higher rate of remodeling. In contrast, when strontium adheres to existing hydroxyapatite, which is a short-term effect, bone strength increases, and solubility reduces. ${ }^{123,124}$ The intake of strontium therefore should be low enough to minimize incorporation into newly formed crystals, but high enough to have an effect on the surface of existing crystals. That is why in preventive strategies, for the time being, additional amounts of strontium close to the suggested daily intakes of 1 to $3 \mathrm{mg}$ might be preferable over therapeutic doses of $170 \mathrm{mg}$.

Fluorine intakes, varying from about 14 to 30 $\mathrm{mg}$ per day, are able to increase BMD of the axial skeleton considerably, but effects on fracture reduction are marginal. The effects on BMD of the hip are much smaller. Due to fluorine incorporation into hydroxyapatite crystals, bending strength might even decrease. ${ }^{1}$ The incorporation of fluorine also decreases solubility and by that remodeling. In time, fluoride concentrations in bone may reach toxic levels. On the one hand, it has been shown in vitro' that high concentrations of fluorine are necessary for the stimulation of os- teoblasts, probably $>26 \mathrm{mg}$ of fluorine per day. ${ }^{138}$ On the other hand, especially low intakes of fluorine were associated with a decreased number of hip fractures in elderly ${ }^{144}$ and late postmenopausal women. ${ }^{146}$ This, and because the anion is bone seeking and has a long residence time, are in favor of a chronic supply of low amounts of fluoride (e.g., by a regular consumption of tea and other fluoride-rich food ingredients). In all cases of increased fluoride consumption, sufficient intakes of calcium and vitamin D are necessary to support a proper mineralization. ${ }^{1,132}$

The role of boron in bone metabolism is especially pronounced in the case of magnesium deficiency. The best effects are seen in patients with arthritis. For these people, the suggested boron requirement of about $1 \mathrm{mg}$ per day ${ }^{150}$ seems to be too low. ${ }^{160}$ In postmenopausal women, the preservation of estrogens ${ }^{8}$ is a positive aspect. The proper dosage of boron, however, is far from clear, ${ }^{158}$ but $3 \mathrm{mg}$ of boron per day already suggests positive effects on bone, ${ }^{149}$ which is within an achievable dietary range.

Although a number of studies have indicated positive effects of vitamin $\mathrm{K}$ on bone health, ${ }^{179,184,205}$ no established causal relationship between vitamin $\mathrm{K}$ deficiency and reduced $\mathrm{BMD}$ or increased fracture rate has been found so far. ${ }^{179}$ Based on the percentage of carboxylated osteocalcin from total osteocalcin, daily vitamin $\mathrm{K}$ intakes should be higher in postmenopausal women than currently recommended. Treatment with additional vitamin $\mathrm{K}$ increased carboxylated osteocalcin ${ }^{189}$ and increased osteoblast activity. ${ }^{183}$ This fits within the well-known role of osteocalcin as a marker of bone formation. However, it has been suggested that osteocalcin especially plays a role in the 'after bone formation' period in the coupling of formation and resorption. ${ }^{180}$ This might also explain why osteocalcin has been found to increase in a late stage of fluoride therapy. ${ }^{136}$ Perhaps other vitamin $\mathrm{K}$-dependent proteins, matrix Gla protein and nephrocalcin in particular, deserve more attention.

Vitamin C seems to play a role in bone formation by stimulating osteoblasts (synthesis of alkaline phosphatase and procollagen) and possibly by inhibition of osteoclasts through stimulating the amidation of calcitonin. This is in line with reported positive associations between vita- 
min $C$ intake and BMD of lumbar spine and hip. ${ }^{6,197.199}$ Based on the capacity of osteoblasts to take up vitamin $\mathrm{C}$, dietary amounts higher than $1000 \mathrm{mg} /$ day are not necessary, but amounts considerably higher than the current recommendations might be beneficial.

Based on the above discussion, it can be concluded that the aforementioned nutrients play a positive role in the delay of natural bone loss (Table 2), although for boron this might only be true when magnesium is deficient. It also can be stated that for the aforementioned nutrients, a considerable increase (dependent on the component 30 to $100 \%$ ) of recommended amounts, ${ }^{94}$ adequate intakes ${ }^{13}$ or doubling of the estimated normal intakes, or less than that already may be very beneficial. Pharmacological amounts, although therapeutically effective, do not seem to be necessary in preventive strategies. Complete foods or supplements are preferred over the supplementation of single nutrients because of the complexity of natural bone loss, the diversity in dietary habitats, and nutrient-nutrient interactions. Prevention or treatment with nutrients is most effective in late postmenopausal women and elderly. Despite only moderate effects in the early postmenopausal stage, additional supplementation may at least overcome the extra bone loss as a result of undernutrition.

\section{REFERENCES}

1. Marcus, R., Feldman, D., and Kelsey, J., Eds. Osteoporosis. Academic Press, Inc, San Diego, 1996, $1373 \mathrm{pp}$.

2. Dempster, D.W. and Lindsay, R. Pathogenesis of osteoporosis, Lancet, 1993; 341: 797-801.

3. Silva, M.J. and Gibson, L.J. Modeling the mechanical behavior of vertebral trabecular bone: effects of agerelated changes in microstructure, Bone, 1997; 21: 191-199.

4. Hodgskinson, R., Njeh, C.F., Currey, J.D., and Langton, C.M. The ability of ultrasound velocity to predict the stiffnes of cancellous bone in vitro, Bone, 1997; 21: 183-190.

5. Eaton-Evans, J. Osteoporosis and the role of diet, $B r$. J. Biomed. Sci., 1994; 51: 358-370.

6. New, S.A., Bolton-Smith, C., Grubb, D.A., and Reid, D.M. Nutritional influences on bone mineral density: a cross-sectional study in premenopausal women, $A m$. J. Clin. Nutr., 1997; 65: 1831-1839.
7. Canalis, E., Hott, M., Deloffre, P., Tsouderos, Y., and Marie, P.J. The divalent strontium salt S12911 enhances bone cell replication and bone formation in vitro, Bone, 1996; 18: 517-523.

8. Beattie, J.H. and Peace, H.S. The influence of a lowboron diet and boron supplementation on bone, major mineral and sex steroid metabolism in postmenopausal women, Br. J. Nutr., 1993; 69: 871-884.

9. Seeman, E., Tsalamandris, C., Bass, S., and Pearce, G. Present and future of osteoporosis therapy, Bone, 1995; 17: 23s-29s.

10. Birchall, J.D. and Espei, A.W. Biological implications of the interaction (via silanol groups) of silicon with metal ions. Proc. Ciba Foundation Symposium 121, Wiley, Chichester, 1986, 140-159.

11. Nordin, B.E.C., Ed., Calcium in Human Biology. Springer-Verlag, London, 1988, $481 \mathrm{pp}$.

12. National Institutes of Health Consensus Panel. Optimal calcium intake, JAMA, 1994; 272: 1942-1948.

13. Standing Committee on the Scientific Evaluation of Dietary Reference Intakes. Dietary reference intakes: calcium, phosphorus, magnesium, vitamin D, and fluoride. National Academy Press, Washington, DC, 1997.

14. Renner, E. Dairy calcium, bone metabolism, and prevention of osteoporosis, J. Dairy Sci., 1994; 77: 34983505.

15. Heaney, R.P., Weaver, C.M., Hinders, S.M., Martin, B., and Packard, P.T. Absorbability of calcium from Brassica vegetables: broccoli, bok choy, and kale, $J$. Food Sci., 1993; 58: 1378-1380.

16. School of Public Health. Health Letter Associates. University of California, Berkeley, 1992; 2(10). 2.

17. Liebman, M. and Chai, W. Effect of dietary calcium on urinary oxalate excretion after oxalate loads, Am. J. Clin. Nutr., 1997; 65: 1453-1459.

18. Whiting, S.J. and Wood, R.J. Adverse effects of highcalcium diets in humans, Nutr. Rev., 1997; 55: 1-9.

19. Eastwood, M. Ed. Principles of Human Nutrition. Chapman \& Hall, London, 1997; 565 pp.

20. Wood, R.J. and Zheng, J.J. High dietary calcium intakes reduce zinc absorption and balance in humans, Am. J. Clin. Nutr., 1997; 65: 1803-1809.

21. Martini, L.A. Magnesium supplementation and bone turnover, Nutr: Rev., 1999; 57: 227-229.

22. Hansen, C., Werner, E., Erbes, H-J., Larrat, V., and Kaltwasser, J.P. Intestinal calcium absorption from different calcium preparations: influence of anion and solubility, Osteoporosis Int., 1996; 6: 386-393.

23. Bronner, F. and Pansu, D. Nutritional aspects of calcium absorption, J. Nutr., 1999; 129: 9-12.

24. Nordin, B.E.C., Need, A.G., Morris, H.A., Horowitz, M., and Robertson, W.G. Evidence for a renal calcium leak in postmenopausal women, J. Clin. Endocrinol. Metab., 1991; 72: 401-407.

25. Riis, B., Thomsen, K., and Christiansen, C. Does calcium supplementation prevent postmenopausal bone loss? A double-blind, controlled clinical study, $N$. Engl. J. Med., 1987; 316: 173-177. 
26. Mackerras, D. and Lumley, T. First- and second-year effects in trials of calcium supplementation on the loss of bone density in postmenopausal women, Bone, 1997; 21: 527-533.

27. Riggs, L.B., O'Fallon, M.W., Muhs, J., O'Connor, M.K., Kumar, R., and Melton, J.L. Long-term effects of calcium supplementation on serum parathyroid hormone level, bone turnover, and bone loss in elderly wornen, J. Bone Miner. Res., 1998; 13: 168-174.

28. Papapoulos, S.E., Lips, P., Pols, H.A.P., Johnston, C.C., and Delmas, P.D., Eds., Osteoporosis 1996. Elsevier Science B.V., Amsterdam, 1996; 407 pp.

29. Kärkkäinen, M.U.M., Wiersma, J.W., and LambergAllardt, C.J.E. Postprandial parathyroid hormone response to four calcium-rich foodstuffs, Am. J. Clin. Nutr., 1997; 65: 1726-1730.

30. Lukert, B., Higgins, J., and Stoskopf, M. Menopausal bone loss is partially regulated by dietary intake of vitamin D, Calcif. Tissue Int., 1992; 51: 173-179.

31. Meunier, P.J., Chapuy, M.C., Arlot, M.E., Delmas, P.D., and Duboeuf, F. Can we stop bone loss and prevent hip fractures in the elderly? Osteoporosis Int., 1994; 4: s71-s76.

32. Chapuy, M.C., Monique, E.A., Duboeuf, F., et al. Vitamin D3 and calcium to prevent hip fractures in elderly women, N. Engl. J. Med., 1992; 327: 16371642.

33. Prestwood, K.M., Pannullo, A.M., Kenny, A.M., Pilbeam, C.C., and Raisz, L.G. The effect of a short course of calcium and vitamin $\mathrm{D}$ on bone turnover in older women, Osteoporosis Int., 1996; 6: 314-319.

34. Elders, P.J.M., Lips, P., Netelenbos, J.C., et al. Longterm effect of calcium supplementation on bone loss in perimenopausal women, J. Bone Min. Res., 1994; 9: 963-970.

35. Heaney, R.P. Bone mass, nutrition, and other lifestyle factors, Nutr. Rev., 1996; 54: s3-s10.

36. Aloia, J.F., Vaswani, A., Yeh, J.K., Ross, P.L., Flaster, E., and Dilmanian, A. Calcium supplementation with and without hormone replacement therapy to prevent postmenopausal bone loss, Ann. Internal Med, 1994; 120: $97-103$

37. Dawson-Hughes, B., Dallal, G.E., Krall, E.A. Sadowski, L., Sahyoun, N., and Tannenbaum, S. A controlled trial of the effect of calcium supplementation on bone density in postmenopausal women, $N$. Engl. J. Med., 1990; 323: 878-883.

38. Breslau, N.A. Calcium, estrogen, and progestin in the treatment of osteoporosis, Osteoporosis, 1994; 20: 691-716.

39. Prentice, A. Is nutrition important in osteoporosis? Proc Nutr Soc., 1997; 56: 357-367.

40. Finkelstein, J.S., Klibanski, A., Schaefer, E.H., Hornstein, M.D., Schiff, I, and Neer, R.M. Parathyroid hormone for the prevention of bone loss induced by estrogen deficiency, $N$. Engl. J. Med., 1994; 331: $1618-1623$

41. Nieves, J.W., Komar, L., Cosman, F., and Lindsay, R. Calcium potentiates the effect of estrogen and calcito- nin on bone mass: review and analysis, Am. J. Clin. Nutr., 1998; 67: 18-24.

42. Chevalley, T., Rizzoli, R., Nydegger, V., et al. Effects of calcium supplements on femoral bone mineral density and vertebral fracture rate in vitamin $D$ replete elderly patients, Osteoporosis Int., 1994; 4: 245-252.

43. Reid, I.R., Ames, R.W., Evans, M.C., Gamble, G.D., and Sharpe, S.J. Long-term effects of calcium supplementation on bone loss and fractures in postmenopaucal women: a randomized controlled trial, Am. J. Med., 1995; 98: 331-335.

44. Nelson, M.E., Fisher, E.C., Dilmanian, F.A., Dallal, G.E., and Evans, W.J. A 1-y walking program and increased dietary calcium in postmenopausal women: effects on bone, Am. J. Clin. Nutr., 1991; 53: 1304 1311.

45. Polley, K.J., Nordin, B.E.C., Baghurst, P.A., Walker, C.J., and Chatterton, B.E. Effect of calcium supplementation on forearm bone mineral content in postmenopausal women: a prospective, sequential controlled trial, J. Nutr., 1987; 117: 1929-1935.

46. Michaëlsson, K., Bergström, R., Holmberg, L. Mallmin, H., Wolk, A., and Ljunghall, S. A high dietary calcium intake is needed for a positive effect on bone density in Swedish postmenopausal women, Osteoporosis Int., 1997; 7: 155-161.

47. Heaney, R.P., McCarron, D.A., Dawson-Hughes, B., et al. Dietary changes favorable affect bone remodeling in older adults, J. Am. Diet. Assoc., 1999; 99: 1228-1233.

48. Reid, I.R., Ames, R.W., Evans, M.C., Gamble, G.D., and Sharpe, S.J. Effects of calcium supplementation on bone loss in postmenopausal women, $N$. Engl. J. Med., 1993; 328: 460-464.

49. Prince, R., Devine, A., Dick, I., et al. The effects of calcium supplementation (milk powder or tablets) and exercise on bone density in postmenopausal women, J. Bone Miner. Res., 1995; 10: 1068-1075.

50. Ravn, P., Clemmesen, B., Riis, B.J., and Christiansen, C. The effect on bone mass and bone markers of different doses of ibandronate: a new bisphosphonate for prevention and treatment of postmenopausal osteoporosis: a 1-year, randomized, double-blind, placebo-controlled dose-finding study, Bone, 1996; 19: $527-533$.

51. Thamsborg, G., Jensen, J.E.B., Kollerup, G., Hauge, E.M., Melsen, F., and Sorensen, O.H. Effect of nasal salmon calcitonin on bone remodeling and bone mass in postmenopausal osteoporosis, Bone, 1996; 18: 207 212.

52. Devogelear, J.P., Broll, H., Correa-Rotter, R., et al. Oral Alendronate induces progressive increases in bone mass of the spine, hip, and total body over 3 years in postmenopausal women with osteoporosis, Bone, 1996; 18: $141-150$

53. Montessori, M.L.M., Scheele, W.H., Netelenbos, J.C., Kerkhoff, J.F., and Bakker, K. The use of Etidronate and calcium versus calcium alone in the treatment of 
postmenopausal osteopenia: results of three years of treatment, Osteoporosis Int., 1997; 7: 52-58.

54. Liberman, U.A., Weiss, S.R., Broll, J., et al. Effect of oral Alendronate on bone mineral density and the incidence of fractures in postmenopausal osteoporosis, N. Engl. J. Med., 1995; 333: 1437-1443.

55. Whiting, S.J. and Lemke, B. Excess retinol intake may explain the high incidence of osteoporosis in Northern Europe, Nutr. Rev., 1999; 57: 192-198.

56. Machlin, L.J., Ed. Handbook of Vitamins. Marcel Dekker, New York, 1991; 595 pp.

57. DeLuca, H.F. and Zierold, C. Mechanisms and functions of vitamin D, Nutr. Rev., 1998; 56: s4-s10.

58. McKenna, M.J., and Freaney, R. Secondary hyperparathyroidism in the elderly: means to defining hypovitaminosis D. Osteoporosis Int., 1998; 8: s3-s6.

59. Vieth, R. Vitamin D supplementation, 25-hydroxyvitamin D concentrations and safety, Am. J. Clin. Nutr., 1999; 69: 842-856.

60. Shearer, M.J. The roles of vitamins $\mathrm{D}$ and $\mathrm{K}$ in bone health and osteoporosis prevention, Proc. Nutr. Soc., 1997; 56: 915-937.

61. Utiger, R.D. The need for more vitamin D, N. Engl. J. Med., 1998; 338: 828-829.

62. Ooms, M.E. Osteoporosis in Elderly Women. Thesis, Vrije Universiteit Amsterdam, 1994; 117 pp.

63. Kinyamu, H.K., Gallagher, J.C., Balhorn, K.E., Petranick, K.M., and Rafferty, K.A. Serum vitamin D metabolites and calcium absorption in normal young and elderly free-living women and in women living in nursing homes, Am. J. Clin. Nutr., 1997; 65: 790-797.

64. Lips, P. De toepassing van vitamine D3 en actieve metabolieten ervan bij preventie en behandeling van osteoporose, Ned. Tijdschr. Geneeskd., 1996; 140: 65-68.

65. Bouillon, R., Carmeliet, G., Daci, E., Segaert, S., and Verstuyf, A. Vitamin D metabolism and action, $O s$ teoporosis Int., 1998; 8: s13-s19.

66. Trang, H.M., Cole, D.E.C., Rubin, L.A., Pierratos, A., Siu, S., and Vieth, R. Evidence that vitamin D3 increases serum 25 -hydroxyvitamin $\mathrm{D}$ more efficiently than does vitamin D2, Am. J. Clin. Nutr., 1998; 68: 854-858.

67. Jacques, P.F., Felson, D.T., Tucker, K.L., et al. Plasma 25-hydroxyvitamin D and its determinants in an elderly population sample. Am. J. Clin. Nutr., 1997; 66: 929-936.

68. Harris, S.S. and Dawson-Hughes, B, Seasonal changes in plasma 25-hydroxyvitamin D concentrations of young American black and white women, Am. J. Clin. Nutr., 1998; 67: 1232-1236.

69. Staal, A., Bemd van den, G.J.C.M., Birkenhäger, J.C., Pols, H.A.P., and Leeuwen van, J.P.T.M. Consequences of vitamin $D$ receptor regulation for the 1,25-dihydroxyvitamin D3-induced 24 hydroxylase activity in osteoblast-like cells: initiation of the C24-oxidation pathway, Bone, 1997; 20: 237-243.
70. Fleet, J.C. Vitamin D receptors: not just in the nucleus anymore, Nutr, Rev., 1999; 57: 60-64.

71. White, C.P., Morrison, N.A., Gardiner, E.M., and Eisman, J.A. Vitamin D receptor alleles and bone physiology, J. Cell Biochem., 1994; 56: 307-314.

72. Wishart, J.M., Horowitz, M., Need, A.G. et al. Relations between calcium intake, calcitriol, polymorphisms of the vitamin D receptor gene, and calcium absorption in premenopausal women, Am. J. Clin. Nutr., 1997; 65: 798-802.

73. Ferrari, S.L., Rizzoli, R., Slosman, D.O., and Bonjour, J-P. Do dietary calcium and age explain the controvery surrounding the relationship between bone mineral density and vitamin $\mathrm{D}$ receptor gene polymorphisms? J. Bone Miner. Res., 1998; 13: 363-370.

74. Wood, R.J. and Fleet, J.C. The genetics of osteoporosis: vitamin D receptor polymorphisms, Annu. Rev. Nutr., 1998; 18: 233-258.

75. Dambacher, M.A. and Schacht, E. Eds., Osteoporosis and Active Vitamin D Metabolites. EULAR Publishers, Basle, 1996; 104 pp.

76. Mee, A.P., Hoyland, J.A., Braidman, I.P., Freemont, A.J., Davies, M., and Mawer, E.B. Demonstration of vitamin $\mathrm{D}$ receptor transcripts in actively resorbing osteoclasts in bone sections, Bone, 1996; 18: 295 299.

77. Reichel, H., Koeffler, H.P., and Norman, A.W. The role of the vitamin $D$ endocrine system in health and disease, N. Engl. J. Med., 1989; 320: 980-992.

78. Bikle, D.D. Role of vitamin D, its metabolites, and analogs in the management of osteoporosis, Osteoporosis, 1994; 20: 759-775.

79. Stryer, L., Ed., Biochemistry. W.H. Freeman and Company, New York, 1995; 1064 pp.

80. Kinyamu, H.K., Gallagher, J.C., Rafferty, K.A., and Balhorn, K.E. Dietary calcium and vitamin D intake in elderly women: effect on serum parathyroid hormone and vitamin D metabolites, Am. J. Clin. Nutr., 1998; 67: 342-348.

81. Aloia, J.F., Vaswani, A., Yeh, J.K., and Russo, L. Differential effects of dietary calcium augmentation and hormone replacement therapy on bone turnover and serum levels of calcitrophic hormones, Osteoporo. sis Int., 1996; 6: 55-62.

82. Komulainen, M., Tuppurainen, M.T., Kröger, H., et al. Vitamin D and HRT: no benefit additional to that of HRT alone in prevention of bone loss in early postmenopausal women. A 2.5-year randomized placebocontrolled study, Osteoporosis Int., 1997; 7; 126-132.

83. Chen, J.T., Shiraki, M., Hasumi, K., et al. 1Hydroxyvitamin D3 treatment decreases bone turnover and modulates calcium-regulating hormones in early postmenopausal women, Bone, 1997; 20: 557562.

84. Tuppurainen, M.T., Komulainen, M., Kröger, $H_{\text {., et }}$ al. Does vitamin $D$ strengthen the increase in femoral neck BMD in osteoporotic women treated with estrogen? Osteoporosis Int., 1998; 8: 32-38. 
85. Torgerson, D.J. and Kanis, J.A. Cost-effectiveness of preventing hip fractures in the elderly population using vitamin D and calcium, Q. J. Med., 1995; 88: 135139.

86. Lips, P., Graafmans, W.C., Ooms, M.E., Bezemer, P.D., and Bouter, L.M. Vitamin D supplementation and fracture incidence in elderly persons: a randomized, placebo-controlled clinical trial, Ann. Intern. Med., 1996; 124: 400-406.

87. Heikinheino, R.J., Inkovaara, J.A., Harju, E.J., et al. Annual injection of vitamin $D$ and fractures of aged bones, Calcif. Tissue Int., 1992; 51: 105-110.

88. Dawson-Hughes, B., Harris, S.S., Krall, E.A., and Dallal, G.E. Effect of calcium and vitamin D supplementation on bone density in men and women 65 years of age or older, N. Engl. J. Med., 1997; 337: 670-676.

89. Meunier, P.J., Sebert, J-L., Reginster, J.Y., et al. Fluoride salts are no better at preventing new vertebral fractures than calcium-vitamin $D$ in postmenopausal osteoporosis, Osteoporosis Int., 1998; 8: 4-12.

90. Dawson-Hughes, B., Harris, S.S., Krall, E.A., Dallal, G.E., Falconer, G., and Green, C. Rates of bone loss in postmenopausal women randomly assigned to one of two dosages of vitamin D, Am J. Clin. Nutr., 1995; 61: $1140-1145$

91. Ferment, O. and Touitou, Y. Regulation hormonale et interrelations metabolique du magnesium, La Presse Medicale, 1988; 17: 584-587.

92. Rude, R.K. and Olerich, M. Magnesium deficiency: possible role in osteoporosis associated with glutensensitive enteropathy, Osteoporosis Int., 1996; 6: 453461.

93. Durlach, J., Bac, P., Durlach, V., Rayssiguier, Y., Bara, M., and Guiet-Bara, A. Magnesium status and aging: an update, Magnes. Res., 1997; 11: 25-42.

94. National Research Council, Ed., Recommended Dietary Allowances. National Academy Press, Washington, D.C. 1989.

95. Driessens, F.C.M. and Verbeeck, R.M.H. On the prevention and treatment of calcification disorders of old age, Med. Hyp., 1988; 25: 131-137.

96. Shils, M.E. Magnesium, calcium, and parathyroid hormone interactions, NY Acad. Sci, 1980; 165-194.

97. Kenney, M.A., McCoy, H., and Williams, L. Effects of magnesium deficiency on strength, mass, and composition of rat femur, Calcif. Tissue Int., 1994; 54: $44-49$.

98. Sojka, J.E. Magnesium supplementation and osteoporosis, Nutr. Rev., 1995; 53: 71-80.

99. Carpenter, T.O., Mackowiak, S.J., Troiano, N., and Gundberg, C.M. Osteocalcin and its message: relationship to bone histology in magnesium-deprived rats, Am. Physiol. Soc., 1992; E107-E114.

100. Schaafsma, G., Van Beresteyn, E.C.H., Raymakers, J.A., and Duursma, S.A. Nutritional aspects of osteoporosis, Wld. Rev. Nutr. Diet., 1987; 49: 121159.
101 Favus, M.J., Ed., Primer on the Metabolic Bone Diseases and Disorders of Mineral Metabolism. Raven Press, New York, 1993; 441 pp.

102. Morrison, M.S. and Amett, T.R. pH effects on osteoclast formation and activation. [Abstract], Bone, 1998; 22; 30s.

103. Ausman, L.M. Criteria and recommendations for vitamin C intake, Nutr. Rev., 1999; 57: 222-224.

104. Traba, M.L., De La Piedra, C., Marin, A., Babé, M., and Rapado, A. Effect of magnesium on the synthesis and distribution of vitamin D metabolites in serum, bone, intestine and kidney, In: Halpern, G., Durlach, J., Eds., Magnesium Deficiency. Karger, Basel, 1985; 227-232.

105. Tucker, K.L., Hannan, M.T., Chen, H., Cupples, L.A., Wilson, P.W.F., and Kiel, D.P. Potassium, magnesium, and fruits and vegetable intakes are associated with greater bone mineral density in elderly men and women, Am. J. Clin. Nutr., 1999; 69: 727-736.

106. Yano, K., Heilbrun, L.K., Wasnich, R.D., Hankin, J.H., and Vogel, J.M. The relationship between diet and bone mineral content of multiple skeletal sites in elderly Japanes men and women living in Hawaii, $A m$. J. Clin. Nutr., 1985; 42: 877-888.

107. New, S.A., Robins, S.P., Campbell, M.K., et al. Dietary influences on bone mass and bone metabolism: further evidence of a positive link between fruit and vegetable consumption and bone health, Am. J. Clin. Nutr., 2000; 71: 142-151.

108. Freudenheim, J.L., Johnson, N.E., and Smith, E.L. Relationships between usual nutrient intake and bonemineral content of women 35 to 65 years of age: longitudinal and cross-sectional analysis, Am. J. Clin. Nutr., 1986; 44: 863-876.

109. Angus, R.M., Sambrook, P.N., Pockock, N.A., and Eisman, J.A. Dietary intake and bone mineral density, Bone Miner., 1988; 4: 265-277.

110. Stendig-Lindberg, G., Tepper, R., and Leichter, I. Trabecular bone density in a two year controlled trial of peroral magnesium in osteoporosis, Magnes. Res., 1993; 6: 155-163.

111. Michaëlsson, K., Holmberg, L., Mallmin, H. et al. Diet and hip fracture risk: a case-control study, Int. J. Epidemol., 1995; 24: 771-782.

112. Cabrera, W.E., Schrooten, I., De Broe, M.E., and D'Haese, P.C. Strontium and bone, J. Bone Min. Res., 1999; 14: 661-668.

113. Wiechen Von, A. and Tait, D. Stabiles Strontium in Milch and Milchpulver in der Bundesrepublic, Deutschland Milchwissenschaft., 1994; 49: 603-607.

114. Florou, H., Savidou, A., and Chaloulou, C. Strontium90 activity in monthly milk samples from Greece, $J$. Dairy Sci., 1996; 79: 1679-1682.

115. Shiraishi, K., Yamamoto, M., Yoshimizu, K., Igarashi, Y., and Ueno, K. Daily intakes of alkaline earth metals in Japanese males, Health Phys., 1994; 66: 30-35.

116. Ghosh, S., Taluker, G., and Sharma, A. Clastogenic activity of strontium chloride on bone marrow cells in vivo, Biol. Tr. Elem. Res., 1990; 25: 51-56. 
117. Morohashi, T., Samo, T., and Yamada, S. Effects of strontium on calcium metabolism in rats. 1. A distinction between the pharmacological and toxic doses, Jpn. J. Pharmacol., 1994; 64: 155-162.

118. Sugihira, N. and Suzuki, K.T. Discrimination between strontium and calcium in suckling rats, Biol. Tr. Elem. Res., 1991; 29: 1-10.

119. Blakely, R.L. Bone strontium in pregnant and lactating females from archaeological samples, Am. J. Phys. Anthrpol., 1989; 80: 173-185.

120. Neufeld, E.B. and Boskey, A.L. Strontium alters the complexed acidic phospholipid content of mineralizing tissues, Bone, 1994; 15: 425-430.

121. Boivin, G., Delpffre, P., Perrat, B., et al. Strontium distribution and interaction with bone mineral in monkey iliac bone after strontium salt (S12911) administration, J. Bone Miner. Res., 1996; 11: 13021311.

122. Reginster, J.Y. Miscellaneous and experimental agents, Am. J. Med. Sci., 1997; 313: 33-40.

123. Okayama, S., Akao, M., Nakamura, S., Shin, Y., Higashikata, M., and Aoki, H. The mechanical properties and solubility of strontium-substitued hydroxyapatite, Bio-Med. Mat. Eng., 1991; 1: 11-17.

124. Christoffersen, J., Christoffersen, M.R., Kolthoff, N., and Bärenholdt, $O$. Effects of strontium ions on growth and dissolution of hydroxyapatite and on bone mineral detection, Bone, 1997; 20: 47-54.

125. Marie, P.J., Garba, M.T., Hott, M., and Miravet, L. Effect of low doses of stable strontium on bone metabolism in rats, Min. Electr. Met., 1985; 11: 5-13.

126. Grynpas, M.D. and Marie, P.J. Effects of low doses of strontium on bone quality and quantity in rats, Bone, 1990; 11: 313-319.

127. Grynpas, M.D., Hamilton, E., Cheung, R., et al. Strontium increases vertebral bone volume in rats at a low dose that does not induce detectable mineralization defect, Bone, 1996; 18: 253-259.

128. Seifert, M.F. and Watkins, B.A. Role of dietary lipid and antioxidants in bone metabolism, Nutr. Res., 1997; 17: $1209-1228$.

129. McCaslin, F.E. and Janes, M.J. The effect of strontium lactate in the treatment of osteoporosis, Proc. Staff. Meet. Mayo Clin., 1959; 95-183.

130. Reginster, J.Y., Roux, C., Jupsin, I., Provvedini, D.M., Birman, P., and Tsouderos, Y. Strontium Ranelate for the prevention of bone loss of early postmenopause [Abstract], Osteoporosis Int., 1998; 8: 12.

131. Robinson, R.G., Preston, D.F., Baxter, K.G., Dusing, R.W., and Spicer, J.A. Clinical experience with strontium- 89 in prostatic and breast cancer patients, Sem. Oncology, 1993; 20: 44-48.

132. Turner, C.H., Boivin, G., and Meunier, P.J. A mathematical model for fluoride uptake by the skeleton, Calcif. Tissue Int., 1993; 52: 130-138.

133. Cao, J., Bai, X., Zhao, Y., et al. Fluorosis induced by drinking brick tea, Fluoride, 1996; 29: 139-143.
134. Turner, C.H., Owan, I., Brizendine, E.J., Zhang, W., Wilson, M.E., and Dunipace, A.J. High fluoride intakes cause osteomalacia and diminished bone strength in rats with renal deficiency, Bone, 1996; 19: 595601.

135. Rao, H.V., Beliles, R.P., Whitford, G.M., and Turner, C.H. A physiologically based pharmacokinetic model for fluoride uptake by bone, Reg. Toxicol. Pharmacol., 1995; 22: 30-42.

136. Patel, S., Chan, J.K.M., and Hosking, D.J. Fluoride pharmacokinetics and changes in lumbar spine and hip bone mineral density, Bone, 1996; 19: 651-655.

137. Balena, R., Kleerekoper, M., Foldes, J.A., et al. Effects of different regiments of sodium fluoride treatment for osteoporosis on the structure, remodeling and mineralization of bone, Osteoporosis Int., 1998; 8: $428-435$.

138. Pak, C.Y.C., Sakhaee, K., Adams-Huet, B., Piziak, V., Peterson, R.D., and Pointdexter, J.R. Treatment of postmenopausal osteoporosis with slow release sodium fluoride, Ann. Intern. Med., 1995; 123: 401408.

139. Caverzasio, J., Palmer, G., and Bonjour, J.-P. Fluoride, mode of action, Bone, 1998; 22: 585-589.

140. Alberts, B., Bray, D., Lewis, J., Raff, M., Roberts, K., and Watson, J.D., Eds. Molecular Biology of the Cell. Garland Publishing, Inc., New York, 1994; 1294 pp.

141. Duursma, S.A., Glerum, J.H., Raymakers, J.A., and Van Dijk, A. Fluoride bij de behandeling van patienten met osteoporose, Ned. Tijdschr. Geneeskd., 1986; 130: 1467-1471.

142. Baud, C.A., Bang, S., and Very, J.M. Minor elements in bone mineral and their effects on its solubility, $J$. Biol. Buccale., 1977; 5: 195-202.

143. Riggs, B.L., Hodgson, S.F., O'Fallon, W.M., et al. Effect of fluoride treatment on the fracture rate in postmenopausal women with osteoporosis, $N$. Engl. J. Med., 1990; 322: 802-809.

144. Lehmann, R., Wapniarz, M., Hofmann, B., Pieper, B., Haubitz, I., and Allolio, B. Drinking water fluoridation: bone mineral density and hip fracture incidence, Bone, 1998; 22: 273-278.

145. Reginster, J.Y., Meurmans, L., Zegels, B., et al. The effect of sodium monofuorophosphate plus calcium on vertebral fracture rate in postmenopausal women with moderate osteoporosis, Ann. Intern. Med., 1998; 129: $1-8$.

146. Ringe, J.D., Kipshoven, C., Coster, A., and Umbach, R. Therapy of established postmenopausal osteoporosis with monofluorophosphate plus calcium: doserelated effects on bone density and fracture rate, $O \mathrm{~s}$ teoporosis Int., 1999; 9: 171-178.

147. Hansson, T. and Roos, B. The effect of fluoride and calcium on spinal bone mineral content: a controlled, prospective ( 3 years) study, Calcif. Tissue Int., 1987; 40: 315-317.

148. Nielsen, F.H. Studies on the relationship between boron and magnesium which possibly affects the formation 
and maintenance of bones, Mag. Tr. Elem., 1990; 9: 61-69.

149. Naghii, M.R. and Samman, $S$. The role of boron in nutrition and metabolism, Prog. Food Nutr. Sci., 1993; 17: 331-349.

150. Volpe, S.L., Taper, L.J., and Meacham, S. The relationship between boron and magnesium status and bone mineral density in the human: a review, Magnes. Res., 1993; 6: 291-296.

151. Nielsen, F.H. Nutritional requirements for boron, silicon, vanadium, nickel and arsenic: current knowledge and speculation, FASEB J., 1991; 5: 2661-2667.

152. Moseman, R.F. Chemical disposition of boron in animals and humans, Environ. Health Perspect., 1994; 102: 113-117.

153. Hunt, C.D., Herbel, J.L., and Nielsen, F.H. Metabolic responses of postmenopausal women to supplemental dietary boron and aluminum during usual and low magnesium intake: boron, calcium, and magnesium absorption and retention and blood mineral concentrations, Am. J. Clin. Nutr., 1997; 65: 803-813.

154. Flynn, A. Minerals and trace elements in milk. Adv. Food Nutr. Res., 1992; 36: 209-252.

155. Shils, M.E., Olson, J.A., and Shike, M., Eds., Modern Nutrition in Health and Disease. Lea \& Febiger, Philadelphia, 1994; $923 \mathrm{pp}$.

156. Biego, G.H., Joyeux, M., Hartemann, P., and Debry, G. Daily intake of essential minerals and metallic micropollutants from foods in France, Sci. Total Environ., 1998; 217: 27-36.

157. Mertz, W. Essential trace elements; new defenitions based on new paradigms, Nutr. Rev., 1993; 51: 287295.

158. McCoy, H., Kenney, M.A., Montgomery, C., Irwin, A., Williams, L., and Orrell, R. Relation of boron to the composition and mechanical properties of bone, Environ. Health Perspect., 1994; 102: 49-53.

159. Nielsen, F.H., Hunt, C.D., Mullen, L.M., and Hunt, J.R. Effect of dietary boron on mineral, estrogen, and testosterone metabolism in postmenopausal women, FASEB J., 1987; 1: 394-397.

160. Newnham, R.E. Essentiality of boron for healthy bones and joints, Environ. Health Perspect., 1994; 102: 8385.

161. Nielsen, F.H. Facts and fallacies about boron, Nutr. Today, 1992; 92: 6-12.

162. Naghii, M.R. and Samman, S. The effect of boron supplementation on its urinary excretion and selected cardiovascular risk factors in healthy male subjects, Biol. Trace Elem. Res., 1997; 56: 273-286.

163. Wimalawansa, S.J., De Marco, G., Gangula, P., and Yallampalli, C. Nitric oxide donor alleviates ovariectomy-induced bone loss, Bone, 1996; 18: 301-304.

164. Vermeer, C., Jie, K-S., and Knapen, M.H.J. Role of vitamin $\mathrm{K}$ in bone metabolism, Annu. Rev. Nutr. 1995; 15: 1-22.

165. Booth. S.L. and Suttie, J.W. Dietary intake and adequacy of vitamin K, J. Nutr., 1998; 128: 785-788.
166. Shearer, M.J., Bach, A., and Kohlmeier, M. Chemistry, nutritional sources, tissue distribution and metabolism of vitamin $\mathrm{K}$ with special reference to bone health, J. Nutr., 1996; 126: 1181s-1186s.

167. Tsaioun, K.I. Vitamin K-dependent proteins in the developing and aging nervous system, Nutr. Rev., 1999; 57: 231-240.

168. Weber, P. Management of osteoporosis: is there a role for vitamin K? Int. J. Vitam. Nutr. Res., 1997; 67: 350-356

169. Schurgers, L.J., Geleijnse, J.M., Grobbee, D.E., et al. Nutritional intake of vitamins $\mathrm{K}_{1}$ (Phylloquinone) and $\mathrm{K}_{2}$ (Menaquinone) in The Netherlands, J. Nutr. Environ. Med., 1999; 9: 115-122.

170. Olson, R.E. The function and metabolism of vitamin K, Ann. Rev. Biochem., 1984; 4: 281-337.

171. Vermeer, C. Nieuwe inzichten omtrent het belang van vitamine $\mathrm{K}$ in voeding, Voeding, 1997; 58: 11-14.

172. Koivu-Tikkanen, T.J., Schurgers, L.J., Thijssen, H.H.W., and Vermeer, C. Intestinal, hepatic, and circulating vitamin $\mathrm{K}$ levels at low and high intakes of vitamin $\mathrm{K}$ in rats, Br. J. Nutr., 2000; 83: 185-190.

173. Kohlmeier, M., Salomon, A., Saupe, J., and Shearer, M.J. Transport of vitamin $\mathrm{K}$ to bone in humans, $J$. Nutr., 1996; 126: 1192s-1196s.

174. Lamon-Fava, S., Sadowski, J.A., Davidson, K.W., O'Brien, M.E., McNamara, J.R., and Schaefer, E.J. Plasma lipoproteins as carriers of phylloquinone ( $\mathrm{Vi}$ tamin K1) in humans, Am. J. Clin. Nutr., 1998; 67: 1226-1231.

175. Vermeer, C., Gijsbers, B.L.M.G., Cracium, A.M., Groenen-Van Dooren, M.M.C.L., and Knapen, M.H.J. Effects of vitamin $\mathrm{K}$ on bone mass and bone metabolism, J. Nutr., 1996; 126: 1187s-1191s.

176. Ferland, G. The vitamin K-dependent proteins: an update, Nutr. Rev., 1998; 56: 223-230.

177. Booth, S.L. Skeletal functions of vitamin K-dependent proteins: not just for clotting anymore, Nutr. Rev., 1997; 55: 282-284.

178. Jie, K.G., Bots, M.L., Vermeer, C., Witteman, J.C., and Grobbee, D.E. Vitamin $\mathrm{K}$ status and bone mass in women with and without aortic atherosclerosis: a population-based study, Calcif. Tissue Int., 1996; 59: 352-356.

179. Binkley, N.C. and Suttie, J.W. Vitamin K nutrition and osteoporosis, J. Nutr., 1995; 125: 1812-1821.

180. Wolf, G.D. Function of the bone protein osteocalcin: definitive evidence, Nutr. Rev., 1996; 54: 332-333.

181. Boskey, A.L., Gadaleta, S., Gundberg, C., Doty, S.B., Ducy, P., and Karsenty, G. Fourier transform infrared microspectroscopic analysis of bones of osteocalcindeficient mice provides insight into the function of osteocalcin, Bone, 1998; 23: 187-196.

182. Liu, G. and Peacock, M. Age-related changes in serum undercarboxylated osteocalcin and its relationships with bone density, bone quality, and hip fracture, Calcif. Tissue Int., 1998; 62: 286-289.

183. Knapen, M.H.J., Jie, K., Hamulyák, K., and Vermeer, C. Vitamin K-induced changes in markers for osteo- 
blast activity and urinary calcium loss, Calcif. Tissue Int., 1993; 53: 81-85.

I 84, Kohlmeier, M., Saupe, J., Shearer, M.J., Schaefer, K., and Asmus, G. Bone health of adult hemodialysis patients is related to vitamin $\mathrm{K}$ status, Kidney Int., 1997; 51: 1218-1221.

185. Knapen, M.H.J., Nieuwenhuijzen Kruseman, A.C., Wouters, R.S.M.E., and Vermeer, C. Correlation of serum osteocalcin fractions with bone mineral density in women during the first 10 years after menopause, Calcif. Tissue Int., 1998; 63: 375-379.

186. Feskanich, D., Weber, P., Willett, W.C., Rockett, H., Booth, S.L., and Colditz, G.A. Vitamin K intake and hip fractures in women; a prospective study. Am. $J$. Clin. Nutr., 1999; 69: 74-79.

187. Knapen, M.H.J., Hamulyák, K., and Vermeer, C. The effect of vitamin $\mathrm{K}$ supplementation on circulating osteocalcin (bone Gla protein) and urinary calcium excretion, Ann. Int. Med., 1989; 111: 1001-1005.

188. Reddi, K, Henderson, B., Meghji, S., et al. Interleukin 6 production by lipopolysaccharide-stimulated human fibroblasts is potentially inhibited by naphthoquinone (vitamin K) compounds, Cytokine, 1995; 7: 287-290.

189. Douglas, A.S., Robins, S.P., Hutchison, J.D., Porter, R.W., Stewart, A., and Reid, D.M. Carboxylation of osteocalcin in post-menopausal osteoporotic women following vitamin $\mathrm{K}$ and $\mathrm{D}$ supplementation, Bone, 1995; 17: 15-20.

190. Sokoll, L.J., Booth, S.L., O'Brien, M.E., Davidson, K.W., Tsaioun, K.I., and Sadowski, J.A. Changes in serum osteocalcin, plasma phyloquinone, and urinary carboxyglutamic acid in response to altered intakes of dietary phylloquinone in human subjects, Am. J. Clin. Nutr., 1997; 65: 779-784.

191. Booth, S.L., O'Brien-Morse, M.E., Dallal, G.E., Davidson, K.W., and Gundberg, C.M. Response of vitamin $\mathrm{K}$ status to different intakes and sources of phylloquinone-rich foods: comparison of younger and older adults, Am. J. Clin. Nutr., 1999; 70: 368-377.

192. Orino, H., Shiraki, M., Fujita, T., Onomura, T., Inoue, $T$., and Kushida, $\mathrm{K}$. Clinical evaluation of menatetrenone in the treatment of involutional osteoporosis - a doubleblind muiti-center comparative study with 1-hydroxy vitamin D3, J. Bone Miner. Res., 1992; 7: s122.

193. Sato, Y., Honda, Y., Kuno, H., and Oizumi, K. Menatetrenone ameliorates osteopenia in disuse-af- fected limbs of vitamin D- and K-deficient stroke patients, Bone, 1998; 23: 291-296.

194. Franceschi, R.T. and Lyer, B.S. Relationship between collagen synthesis and expression of the osteoblast phenotype in MCT3T3-E1 cells, J. Bone Min. Res., 1992; 7: 235-246.

195. Franceschi, R.T, Wilson, J.X., and Dixon, S.J. Requirement for Na+-dependent ascorbic acid transport in osteoblast function, Am. Physiol. Soc., 1995; C1430C1439.

196. Wolf, G. The mechanism of uptake of ascorbic acid into osteoblasts and leukocytes, Nutr. Rev., 1996; 54: $150-152$

197. Wang, M-C., Villa, M.L., Marcus, R., and Kelsey, J.L. Associations of vitamin C, calcium and protein with bone mass in postmenopausal Mexican-American women, Osteoporosis Int., 1997; 7: 533-538.

198. Hall, S.L. and Greendale, G.A. The relation of dietary vitamin $C$ intake to bone mineral density: results from the PEPI study, Calcif. Tissue Int., 1998; 63: 183189.

199. Leveille, S.G., LaCroix, A.Z., Koepsell, T.D., Beresford, S.A., Van Belle, G., and Buchner, D.M. Dietary vitamin $C$ and bone mineral density in postmenopausal women in Washington State, USA, $J$. Epidemiol. Community Health, 1997; 51: 479-485.

200. Krishnamra, N., Saengumnart, W., and Limlomwongse, L. Dietary calcium bioavailability and a search for calcium supplement sources for Thai people: a review, J Sci soc Thailand, 1992; 18: 73-91.

201. Heaney, R.P., Dowell, M.S., and Barger-Lux, M.J. Absorption of calcium as the carbonate and citrate salts, with some observations on method, Osteoporosis Int., 1999; 9: 19-23.

202. Holbrook, T.L., Barret-Connor, E., and Wingard, D.L. Dietary calcium and risk of hip fracture: 14-year prospective population study, Lancet, 1988; 1046-1049.

203. Driessens, F.C.M. Magnesium en verkalking, Nat. Techn., 1993; 61: 324-335.

204. Reginster, J.Y., Halkin, V., Henrotin, Y., and Gosset, C. Treatment of osteoporosis: role of bone-forming agents, Osteoporosis Int., 1999; 3; s91-\$96.

205. Tamatani, M., Morimoto, S., Nakajima, M., et al. Decreased circulating levels of vitamin $\mathrm{K}$ and 25hydroxyvitamin D in osteopenic elderly men, $\mathrm{Me}$ tabolism, 1998; 47: 195-199. 